\title{
THE AUSTRALIAN GOVERNMENT'S USE OF THE MILITARY IN AN EMERGENCY AND THE CONSTITUTION
}

\begin{abstract}
ANTHONY GRAY*
Australia has recently endured a very trying bushfire season and is currently enduring a worldwide pandemic with COVID-19. These events raise very significant legal issues, including the powers of the federal government to deal with emergency situations. A particularly noteworthy feature of the federal government's response to these crises has been the use of Defence Force personnel to implement its policy decisions. This article considers the federal government's powers to respond to emergency situations, including the use of the military.
\end{abstract}

\section{INTRODUCTION}

Australia recently endured a natural disaster, and is currently enduring a global pandemic of the scale not seen for a century. The 2019-20 summer was one of the most difficult fire seasons on record. According to the Center for Disaster Philanthropy, 34 people lost their lives from bushfires. Approximately 46 million acres of land were affected. The overall economic impact was estimated at more than $\$ 4.4$ billion. ${ }^{1}$ There has been significant pressure on the Australian Government to respond to the crisis. Its first response, that firefighting was a state/territory (constitutional) responsibility, not a federal one, was not wellreceived. Subsequently it ramped up its response.

On 29 January 2020, during a speech to the National Press Club, Prime Minister Morrison stated:

I believe, however, there is now a clear community expectation that the Commonwealth should have the ability to respond in times of national emergencies and disasters, particularly through deployment of our defence forces in circumstances where the life and property of Australians have been assessed to be under threat ... that means examining the constitutional and legal framework to allow the federal government to declare a national state of emergency ... with clear authorities and appropriate safeguards for Commonwealth action on its own initiative, including the deployment of our defence force. ${ }^{2}$

\footnotetext{
* $\quad$ Professor and Associate Head - Research, USQ School of Law and Justice. Thanks to the anonymous reviewers for very helpful comments on an earlier draft.

1 '2019-2020 Bushfires', Center for Disaster Philanthropy (Web Page, 9 September 2019, updated October 2020) <https://disasterphilanthropy.org/disaster/2019-australian-wildfires/>.

2 Scott Morrison, 'Address' (Speech, National Press Club, 29 January 2020) $<$ https://www.pm.gov.au/media/address-national-press-club $>$.
} 
The Australian Government enlisted members of the Australian Defence Force ('ADF') to assist with aspects of the bushfire crisis, including evacuations and recovery efforts. ${ }^{3}$ This was not unprecedented; members of the ADF have assisted in other natural disasters including the Black Saturday bushfires in 2009. However, questions have been asked about the federal government's constitutional reach in using the ADF in this way. ${ }^{4}$

Unfortunately, one emergency situation followed another. The country is currently enduring the COVID-19 crisis, a global pandemic not seen for many decades. The crisis is particularly acute, involving a health crisis; trying to minimise disease spread, at least until a vaccination is found; providing medical assistance to victims; and an economic crisis, with sections of the economy in 'hibernation'. Each state/territory has enacted measures, including severe restrictions on movement across borders, and sometimes intra-jurisdictionally, to minimise spread.

The engagement of the ADF here has been noteworthy. The Defence Minister has confirmed defence personnel have been utilised at COVID-19 coordination centres, providing clinical and epidemiological support, assisting with transport and logistics, repatriating Australian citizens, and assisting in face mask and hand sanitiser production. ${ }^{5}$

These crises also raise questions about the Australian government's role in emergency response. While its constitutional power regarding quarantine for those suspected of being infected is clear, ${ }^{6}$ as are rules it might impose regarding international or interstate trade and commerce, ${ }^{7}$ and the massive fiscal stimulus packages to limit economic fallout, ${ }^{8}$ in other respects the federal government's constitutional power is unclear. It has been reported the federal government is

3 Some of these are documented in 'Operation Bushfire Assist 2019-2020', Department of Defence (Web Page, 13 March 2020) < https://news.defence.gov.au/national/operation-bushfire-assist-2019-2020>, and include clearing roads, mending fences, clearing firebreaks, purifying water and delivering cargo. Members of the ADF were also involved in large-scale evacuations from Mallacoota, Victoria: Claire Burnet, 'Full Circle: Mallacoota Evacuees Flown Home', Department of Defence (Web Page, 22 January $2020)<$ https://news.defence.gov.au/national/full-circle-mallacoota-evacuees-flown-home>.

4 Elizabeth Ward, 'Call Out the Troops: An Examination of the Legal Basis for Australian Defence Force Involvement in "Non-Defence" Matters' (Research Paper No 8, Parliamentary Library, Parliament of Australia, 24 November 1997) 42, who, in referring to the use of defence forces for 'non-defence' purposes, concludes '[e]xperience has shown first that successive Commonwealth Governments are quite happy to call on the forces, with little or no prior consideration of the legal basis for their involvement'; Janine Fetchik " "Left and Right of Arc": The Legal Position of the Australian Defence Force in Domestic Disaster Response Using the 2009 "Black Saturday" Victorian Bushfires as a Case Study' (2012) 27(2) Australian Journal of Emergency Management 31, 36.

5 Linda Reynolds, 'Defence Provides Additional Assistance in Response to COVID-19' (Media Release, 23 March 2020) <https:/www.minister.defence.gov.au/minister/lreynolds/media-releases/defenceprovides-additional-assistance-response-covid-19>.

6 Australian Constitution s 51(ix).

7 Ibid s 51(i).

8 This is given in the decision of the High Court in Pape $v$ Commissioner of Taxation (2009) 238 CLR 1 ('Pape') (discussed later). 
using defence personnel to police restrictions on interstate movement, as state borders have been closed, ${ }^{9}$ although the constitutional basis for this is unclear.

No doubt, it was intended at Federation that response to emergencies caused by natural disasters like bushfires, floods and health issues would be a responsibility of state, not federal, governments. ${ }^{10}$ Individual states and territories have specific legislation dealing with emergencies. ${ }^{11}$ However, times have changed since then. In the case of the recent bushfire season, problems extended beyond one state. With COVID-19, the problem is national and international in scope, and of a scale and kind the founding fathers may not have foreseen.

It becomes critical to consider what powers the federal government has in this field of 'emergency response'. It is trite to observe the federal government has not passed emergency services legislation of the kind that exists sub-nationally. It lacks legislative power to declare a state of emergency, with the consequences this would typically have. ${ }^{12}$ There have been calls for reform here, and model laws drawn up. ${ }^{13}$ The question of its constitutional powers to deal with emergencies has become topical. $^{14}$

Its importance is only heightened by the High Court decision in Pape $v$ Commissioner of Taxation ('Pape'). ${ }^{15}$ There, the Court recognised restrictions on the constitutional ability of the federal government to spend money. Previously, it was thought practically impossible to constitutionally challenge a Commonwealth appropriation. In Pape, the Court opened the door to such challenges, finding the Commonwealth, if challenged, would need to demonstrate particular spending was pursuant to a head of power, primarily those in section 51 of the Constitution. Previously, it was thought the section of the Constitution that authorises Commonwealth appropriations of money, section 81, might act as head of power for it to (validly) spend money. Pape closed this window. In theory now, the federal government must point to (another) head of power to support its spending. It cannot rely on section 81 . This is not the place to critique that decision, and I

9 Ainsley Koch, 'Visitors Warned to Go Home if They Don't Self-Isolate as NT Borders Close', Nine News (online, 24 March 2020) < https://www.9news.com.au/national/coronavirus-nt-borders-closevisitors-warned-to-go-home-if-they-dont-self-isolate/90b641df-494c-4881-ad4e-41d39750edf8>. The article suggests that 'Australian Defence Force personnel have also been deployed to assist police at border entry checkpoints'.

10 Michael Eburn, Cameron Moore and Andrew Gissing, The Potential Role of the Commonwealth in Responding to Catastrophic Disasters (Report No 530, Bushfire and Natural Hazards Cooperative Research Centre, May 2019) 5.

11 State Emergency and Rescue Management Act 1989 (NSW); Emergency Management Act 1986 (Vic); Emergency Management Act 2013 (Vic); Disaster Management Act 2003 (Qld); Emergency Management Act 2005 (WA); Emergency Management Act 2004 (SA); Emergency Management Act 2006 (Tas); Emergencies Act 2004 (ACT); Emergency Management Act 2013 (NT). See for discussion Hoong Phun Lee et al, Emergency Powers in Australia (Cambridge University Press, $2^{\text {nd }}$ ed, 2018) 179-99.

12 Justice François Kunc 'Flood and Fire and Famine' (2020) 94(3) Australian Law Journal 167, 168.

13 Eburn, Moore and Gissing (n 10); Michael Ernest Eburn, 'Australia’s International Disaster Response: Laws, Rules and Principles' (PhD Thesis, Monash University, 2009).

14 This is notwithstanding the important practical point that, at least in most cases, the Commonwealth enjoys 'de facto' power given it is very unlikely that an individual or government entity will constitutionally challenge the federal government's exercise of powers, described by Eburn, Moore and Gissing as a classic catch-22 situation: Eburn, Moore and Gissing (n 10) 19. 
have done this elsewhere. ${ }^{16}$ What is relevant for current purposes is that the consequence of Pape is to sharpen focus on the extent to which the Commonwealth has a head of power to support spending. Clearly, Commonwealth spending is part of the solution to the COVID-19 emergency.

For current purposes, I will leave several matters to one side, because I discuss them in other work, or my judgment is that the constitutional position is relatively clear. I will not consider the Commonwealth's quarantine power, obviously relevant to COVID-19. I have considered it elsewhere. ${ }^{17}$ For the same reason, I will not consider legal protection of freedom of association, currently under assault by lockdown-type measures on individuals, and restricted public gatherings ${ }^{18}$ Nor will I consider the possibility that states might refer their power to the Commonwealth to permit it to legislate through section 51(xxxviii), nor the constitutional validity of direct section 96 grants by the Commonwealth to states. This power has been interpreted broadly, ${ }^{19}$ and there is little argument about its ambit. I will not consider the constitutional validity of the federal government's financial stimulus/recovery packages legislated in response to COVID-19. This is because Pape supports the Commonwealth's constitutional ability to respond financially to economic shocks like the 2008 Global Financial Crisis was, and which the COVID-19 crisis is. The Court has affirmed Pape. ${ }^{20}$ Thus, it is likely that, if asked to consider the constitutional validity of the financial response, it would validate it. Thus, this issue will not be considered.

This article will consider the constitutional validity of using the ADF in the recent crises. It is structured as follows. Part I explains the possible legislative basis for the Commonwealth's use of the military. Part II explains the defence power, and whether it might support the use of the ADF in response to it, pursuant to the Defence Act 1903 (Cth) ('Defence Act'). Part III explains the Commonwealth's executive power in section 61 and/or so-called inherent nationhood power, and incidental power in section 51(xxxix), and whether they might support use of

16 Anthony Gray 'Federal Spending Power in Three Federations: Australia, Canada and the United States' (2011) 40(1) Common Law World Review 13.

17 Anthony Gray 'The Australian Quarantine and Biosecurity Legislation: Constitutionality and Critique' (2015) 22(4) Journal of Law and Medicine 788. See, on the use of regulations under biosecurity legislation, Andrew Edgar 'Law-Making in a Crisis: Commonwealth and NSW Coronavirus Regulations' (Web Page, 30 March 2020) <https://auspublaw.org/2020/03/law-making-in-a-crisis-commonwealth-andnsw-coronavirus-regulations/>.

18 Anthony Gray 'Freedom of Association in the Australian Constitution and the Crime of Consorting' (2013) 32(2) University of Tasmania Law Review 149. In any event, the High Court has not shown particular enthusiasm for any suggested freedom of association, insisting that, if it exists at all, it could only be a 'corollary' to the implied freedom of political communication (effectively minimising it): Wainohu v New South Wales (2011) 243 CLR 181, 230 (Gummow, Hayne, Crennan and Bell JJ); tending to decide cases which potentially involve freedom of association questions on other grounds: South Australia v Totani (2010) 242 CLR 1; and simply rejecting assertions of such freedom of association: Tajjour v New South Wales (2014) 254 CLR 508.

19 Victoria $v$ Commonwealth (1957) 99 CLR 575.

20 Williams $v$ Commonwealth (2012) 248 CLR 156 ('Williams [No 1]'). 
military in the response to both crises. ${ }^{21}$ Part IV considers restrictions on the movement of individuals across state borders, given the involvement of the military in policing such restrictions. While the main focus will be on use of the military in emergency situations, the discussion will also be relevant to broader questions of the federal government's power to deal with emergencies, other than involving the use of defence personnel.

\section{A The Relevant Legislation}

It must firstly be acknowledged that, at the time of writing, the Australian Government has not called out the military for the bushfire or COVID-19 crisis, pursuant to sections 33 or 35 of the Defence Act. ${ }^{22}$ The discussion below considers the constitutional questions that would arise if the Government were to make such a call-out. This would be contentious, because the involvement of the military in a civilian setting is contentious in public consciousness. ${ }^{23}$

Several sections of the Defence Act are important. They are primarily contained within part IIIAAA. Of particular interest are Commonwealth interest orders and contingent interest orders in sections 33-6. Section 33 permits the ADF to be 'called out' in order to 'protect Commonwealth interests'. Section 33(1) permits the Governor-General to make an order if the relevant Minister is satisfied any one of three states of affairs exists. The first is if 'domestic violence' that would be likely to affect Commonwealth interests is likely to occur in Australia. The others include an aspect of threats to the Australian offshore area, so these will not be discussed. The power applies where the Governor-General believes the ADF should be called out/utilised to protect the nation against the domestic violence and/or threat. ${ }^{24}$ In so deciding, they must consider the nature of the

21 Note also section 119 of the Australian Constitution, obliging the Commonwealth to protect states against invasion and (on application by the state government) against 'domestic violence'. This section is virtually identical to article IV section 4 of the United States Constitution, from which it was derived: John Quick and Robert Rudolph Garran, The Annotated Constitution of the Australian Commonwealth (Angus and Robertson, 1901) 964-5; Justice Robert Hope, Parliament of Australia, Protective Security Review (Parliamentary Paper No 397, 15 May 1979) 150 ('Hope Protective Security Review'); see also Sir Victor Windeyer, 'Opinion of Sir Victor Windeyer, KBE, CB, DSO, On Certain Questions Concerning the Position of Members of the Defence Force When Called Out to Aid the Civil Power' (Appendix No 9, 13 November 1978) in Hope Protective Security Review (n 21) 277, 280 [7] noting the relevance of the United States Supreme Court's interpretation of article IV $\S 4$ of the United States Constitution in Re Debs 158 US 564, 582 (Brewer J) (1895) to section 119 of the Australian Constitution - that interpretation being that

the entire strength of the nation may be used to enforce in any part of the land the full and free exercise of all national powers, and the security of all rights entrusted by the Constitution to its care ... if the emergency arises, the army of the nation and all its militia are at the service of the nation to compel obedience to its laws.

22 David Letts 'Sending in the Military? First Let's Get Some Legal Issues Straightened Out', Canberra Times (online, 8 January 2020) <https://www.canberratimes.com.au/story/6570161/sending-in-themilitary-first-lets-get-some-legal-issues-straightened-out/>.

23 Michael Head, Domestic Military Powers, Law and Human Rights: Calling Out the Armed Forces (Routledge, 2020) 143.

24 See for discussion Cameron Moore, "To Execute and Maintain the Laws of the Commonwealth" the ADF and Internal Security: Some Old Issues with New Relevance' (2005) 28(2) University of New South 
domestic violence, and whether utilisation of the ADF will likely enhance the ability of states and territories to protect Commonwealth interests against the domestic violence. ${ }^{25}$ The making of such order is not dependent on state request. ${ }^{26}$

The Defence Act does not define 'domestic violence' in this context. ${ }^{27}$ It merely refers to the meaning of this expression in section 119 of the Constitution. No case provides guidance on what this section of the Constitution means, ${ }^{28}$ because it has been little utilised. Thus, it is not clear whether an emergency caused by a natural disaster or pandemic would qualify as 'domestic violence'. Obviously, a narrow reading of 'violence' would suggest a need for physical violence, so the section might be interpreted as limited to cases where actual violence is occurring. This argument finds support in the Explanatory Memorandum relevant to part IIIAAA. In explaining that the Governor-General must consider the nature of the domestic violence, to determine whether or not an order should be made, it states such matters for consideration might include types of violence, types of weapons used, and the number of perpetrators. It discusses examples of violence to include 'chemical, biological, radiological or nuclear ... attack', as well as 'active shooter(s), ${ }^{29}$

In contrast, the word 'violence' could be applied broadly. In the context of the field of 'domestic violence', it has been interpreted broadly and non-literally; it is recognised that the concept must extend beyond physical violence, to include emotional abuse, for example. My reading of the Explanatory Memorandum is that it provides examples of the kind of situations contemplated by 'domestic violence'. However, the discussion and examples given were not intended to provide an exhaustive definition of the concept. Given that section 31 of the Defence Act states the phrase 'domestic violence' is to have the same meaning as the identical phrase in section 119 of the Constitution, and that it is for the High Court to interpret the Constitution, and that most accept that the meaning of words in the Constitution can change over time, ${ }^{30}$ it is for the High Court to determine the scope of the phrase

Wales Law Journal 523; Norman Charles Laing, 'Call-Out the Guards: Why Australia Should No Longer Fear the Deployment of Australian Troops on Home Soil' (2005) 28(2) University of New South Wales Law Journal 507.

25 Defence Act 1903 (Cth) s 33(2)(ii); Michael Head points out that this is an expansion from the previous threshold, which required that the federal government be satisfied the individual states or territories would be unable themselves to provide the needed protection: Michael Head 'Another Expansion of Military Call Out Powers in Australia: Some Critical Legal, Constitutional and Political Questions' [2019] (5) University of New South Wales Journal Forum 1, 5.

26 Defence Act 1903 (Cth) s 38(1). The Commonwealth should consult with the relevant states and territories prior to acting, but are excused where this is impractical: at ss 38(2)-(3).

27 Head, 'Another Expansion of Military Call Out Powers in Australia: Some Critical Legal, Constitutional and Political Questions' (n 25) 1; Head, Domestic Military Powers, Law and Human Rights: Calling Out the Armed Forces (n 23) 142.

28 Lee et al (n 11) 225; Peta Stephenson 'Fertile Ground for Federalism? Internal Security, the States and Section 119 of the Constitution' (2015) 43 Federal Law Review 289, 298. Stephenson states section 119 reflects article IV $\S 4$ of the United States Constitution, where 'domestic violence' has been interpreted to mean 'local uprisings, insurrections or internal unrest within a state'.

29 Explanatory Memorandum, Defence Amendment (Call Out of the Australian Defence Force) Bill 2018 (Cth) [180]-[181].

30 Grain Pool of Western Australia v Commonwealth (2000) 202 CLR 479, 495 (Gleeson CJ, Gaudron, McHugh Gummow, Hayne and Callinan JJ). 
'domestic violence' for the purposes of section 119, and thus part IIIAAA of the Defence Act. There is a logical circuity in any suggestion the federal Parliament could control the meaning of the phrase 'domestic violence' in section 119 of the Australian Constitution, since it imposes an obligation on it. ${ }^{31}$

Thus, a court today might apply the concept of 'domestic violence' within section 33 of the Defence Act in a similarly liberal and non-literal way to include emergency situations. It might be argued, for instance, that, consistent with the comments of Sir Victor Windeyer, ${ }^{32}$ domestic violence includes something like a rupture to the social fabric, so an emergency situation not involving actual or threatened violence might qualify. It may be there is value in flexibly interpreting the meaning of the provision since, as with the use of the executive power more generally (discussed below), it is difficult to anticipate in advance all circumstances in which it might apply. ${ }^{33}$

Similar interpretation issues attend section 35 of the Defence Act, permitting the Governor-General to make an order to protect a state/territory against 'domestic violence'. However, exercise of this power is conditional upon that government seeking protection. This occurred (at least informally) in respect of the Victorian bushfires during the 2019-2020 bushfire event, where Victoria obtained Commonwealth assistance to evacuate isolated people in the state. ${ }^{34}$ It has also occurred during COVID-19, with members of the military accompanying state police to enforce quarantine orders and restrictions. Both sections 33 and 35 have equivalent provisions regarding contingencies. ${ }^{35}$ The ADF may also be declared a national response agency under section 452 of the Biosecurity Act 2015 (Cth), ${ }^{36}$ and thus have powers delegated to it.

In cases of 'sudden and extraordinary emergency, ${ }^{37}$ the Prime Minister or two ministers (sometimes) can make the orders, not the Governor-General. However, these decision-makers need not be satisfied of the requirements usually necessary in order to attract the exercise of powers referred to in sections 33-6 by the Governor General. ${ }^{38}$ Specifically, it would not need to be shown a situation of 'domestic violence' existed before the Commonwealth could call out the military in cases of 'sudden and extraordinary emergency'.

Where a call out order is made, the Defence Act requires the ADF to cooperate closely with state/territory law enforcement authorities, and not be engaged in any specific task within those jurisdictions unless requested by the state/territory to do

31 For a similar argument regarding interpretation of a head of power, see Anthony Gray 'The Meaning of an Alien in the Constitutional Universe' (2013) 20(2) Australian Journal of Administrative Law 89.

32 Windeyer (n 21) 284 [17].

33 Cameron Moore, Crown and Sword: Executive Power and the Use of Force by the Australian Defence Force (ANU Press, 2017) 14 ('Crown and Sword'). Moore states 'there is a need for an executive power to be available continually, not only occasionally, and to respond to the unexpected'.

34 Kunc (n 12) 168.

35 These are sections 34 and 36 respectively.

36 My research has not been able to confirm that such a declaration has been made in response to the COVID-19 situation. See for discussion John Tarrant and Christopher Minus, 'ADF Powers to Arrest, Detain and Remove Civilians' in Robin Creyke, Dale Stephens and Peter Sutherland (eds), Military Law in Australia (Federation Press, 2019) 150-1.

37 Defence Act 1903 (Cth) s $51 \mathrm{U}$.

38 Ibid s 51U(4)(a). 
so. This is as far as it is reasonably practical. ${ }^{39}$ Section 46 permits a Minister to confer special powers upon members of the ADF that have been called out. They are potentially broad. They might include, relevantly, taking action to prevent or end threats to a person's health or safety, or public health and safety, ${ }^{40}$ control the movement of individuals, ${ }^{41}$ evacuate them,${ }^{42}$ to search and seize persons, things or property, ${ }^{43}$ detain them pursuant to the call-out order, ${ }^{44}$ require persons to answer questions or produce documents where easily accessible, ${ }^{45}$ and patrolling areas. ${ }^{46}$

Section 51L permits a member of the ADF pursuant to a call out order made under sections 33 or 35 , to do the following in protecting 'declared infrastructure': ${ }^{47}$

(a) prevent damage or disruption to its operation;

(b) prevent or end acts of violence or threats to any person's life, health or safety or public health or safety;

(c) protect anyone from acts of violence or threats to any person's life, health or safety, or public health or safety.

Section 51L(3) states the person may, in the course of such action, control movement of persons or means of transport, evacuate people to safety, search people or things pursuant to carrying out the order, detain a person pursuant to carrying out the order, and require a person to answer questions or provide a readily available document. ${ }^{48}$

The final provision of this part, section 51ZD, is important. It makes clear that Parliament did not intend that part IIIAAA should operate as a code to govern all circumstances in which the Commonwealth might enlist members of the ADF to protect Commonwealth interests. This permits the Commonwealth, for instance, to argue that it has powers other than those specifically referred to in the part to deal with internal emergencies including, but not limited to, the Commonwealth prerogative power. ${ }^{49}$ The utility of such availability is noted.$^{50}$ The constitutional basis of such activity is considered below.

39 Ibid s 40.

40 Ibid ss 46(5)(b)(ii), (c)(ii).

41 Ibid s 46(7)(b).

42 Ibid s 46(7)(c).

43 Ibid ss 46(7)(d)-(e).

44 Ibid s 46(7)(f).

45 Ibid s 46(7)(h).

46 Ibid s 46(7)(g). On searches more generally in 'designated areas', see s 51A.

47 This is defined in $\mathrm{s} 51 \mathrm{H}$.

48 There are broader policy questions here regarding the growing influence of the military in civilian life, as to which, see Pauline Therese Collins, Civil-Military 'Legal' Relations: Where to From Here? The Civilian Courts and the Military in the United Kingdom, United States and Australia (Brill Nijhoff, 2018).

49 Moore, Crown and Sword (n 33) 174.

50 '[I]t is vital that the executive power remains available on either side of a pt IIIAAA call-out in order to manage both preconditional requirements and, if necessary, post-call-out consequences': David Letts and Rob McLaughlin, 'Call-Out Powers for the Australian Defence Force in an Age of Terrorism: Some Legal Implications' (2016) 85 AIAL Forum 66, 77. 
As Letts and McLaughlin note, part IIIAAA has not yet been considered in case law. ${ }^{51}$ This is explained by the fact no call outs have yet been activated operationally under either sections 33 or 35 . Contingent powers were potentially engaged, but not utilised. This partly explains why, as noted by Saultry and Copeland, ${ }^{52}$ the Commonwealth has not publicly articulated the constitutional basis of this part of the legislation.

This paper will now consider whether provisions such as these, that potentially could be utilised to enlist the ADF in the bushfire and COVID-19 crises, are constitutionally valid. ${ }^{53}$ It is acknowledged again that the ADF has not been called out under section 33 or section 35 of the Defence Act. The Governor-General called out the military under section 28 for the bushfire disaster. This permits reservists to provide continuous full-time service. It does not confer powers.

Their possible unconstitutionality has been canvassed in the literature. ${ }^{54}$ Michael Head refers to a 'plethora of constitutional doubts' and questions whether they are supported by a head of power. ${ }^{55}$ Cameron Moore states ' $[t]$ here simply is not an identifiable authority in law for everything the executive does, particularly the ADF' ${ }^{56}$ It is axiomatic in a constitutional system of government, with the rule of law at its heart, that there must be such a basis. ${ }^{57}$

In January 2020, Prime Minister Scott Morrison was quoted acknowledging that employment of the military to respond to the bushfire crisis 'pushed the constitutional authorities' for us to act 'to its very edge'. ${ }^{58}$ This article seeks to resolve those doubts, and determine whether the Commonwealth has gone 'over the (constitutional) edge'. Three questions are asked, involving the Commonwealth's defence power, executive power, and questions around freedom of intercourse among the states within section 92 of the Constitution. In so doing, broader points regarding the executive power will be made, other than merely on the use of the military. Needless to say, this article is not a commentary on whether the Commonwealth actions were useful or beneficial, or a good idea.

51 David Letts and Rob McLaughlin, 'Military Aid to the Civil Power' in Creyke, Stephens and Sutherland (eds) (n 36) 129.

52 Penny Saultry and Damian Copeland, 'Domestic Legal Framework for Operations' in Creyke, Stephens and Sutherland (eds) (n 36) 162.

53 It is a separate question whether they are adequate. For critique in this regard, see ibid 171.

54 Head, 'Another Expansion of Military Call Out Powers in Australia: Some Critical Legal, Constitutional and Political Questions’ (n 25).

55 ' $[\mathrm{I}] \mathrm{t}$ seems that a plethora of constitutional doubts has been deepened, particularly by the greater capacity of the Federal Government and the ADF to deploy troops without any state or territory request and to disregard state and territory objections. Not only do the provisions arguably exceed the boundaries of section 119 of the Constitution, they may also lack a sufficient connection to the defence power or other federal heads of power': ibid 13-14.

56 Moore, Crown and Sword (n 33) 51.

57 Australian Communist Party v Commonwealth (1951) 83 CLR 1, 193 (Dixon J) ('Australian Communist Party Case'). Dixon J stated that the rule of law formed an 'assumption' underlying the Australian Constitution.

58 Matthew Doran, 'Scott Morrison to Take Proposal for Bushfire Royal Commission to Cabinet', $A B C$ News (online, 12 January 2020) <https://www.abc.net.au/news/2020-01-12/bushfire-royal-commissionproposal-to-go-to-cabinet-morrison/11860954>. 


\section{COMMONWEALTH DEFENCE POWER}

\section{A Introduction}

Section 51(6) authorises the Commonwealth to make laws for the "naval and military defence' of the Commonwealth and States. ${ }^{59}$ Defence was critical in the movement towards federation. ${ }^{60}$ This power is unusual. Firstly, it is a purposive power, not one with respect to a particular subject matter. ${ }^{61}$ This has the practical consequence that the Commonwealth must show with particularity how given measures relate to a defence purpose, or furthers the defence effort. ${ }^{62}$ If it cannot demonstrate this, the law will not be supported by section 51(vi). It will be declared invalid, unless the Commonwealth can rely on another head of power. Questions of proportionality are relevant. The High Court has generally increased the use of proportionality in constitutional law. It has applied proportionality-type reasoning to purposive powers like the defence power for many years. ${ }^{63} \mathrm{~A}$ law that is not sufficiently proportional to the purpose of defence is not supported by the defence power.

The second way in which it is unusual is that it expands and contracts, depending on the situation, in a manner unique among the Commonwealth's constitutional heads of power. ${ }^{64}$ In other words, it has a primary aspect, which is perennial, and a secondary aspect, which assumes particular importance during wartime. ${ }^{65}$

Section 51(vi) has a second limb, permitting the Commonwealth 'control of the forces to execute and maintain the laws of the Commonwealth'. Most case law concerning section 51(vi) focusses on the first limb. ${ }^{66}$ It may be that given the interpretation given to section 51(vi) in Thomas $v$ Mowbray, discussed below, the second limb of section 51(vi) is largely encompassed within the first, and somewhat redundant. ${ }^{67}$

59 These are not words of limitation: Farey v Burvett (1916) 21 CLR 433, 440 (Griffith CJ) ('Farey').

60 Quick and Garran (n 21) 561-3.

61 Stenhouse v Coleman (1944) 69 CLR 457, 471 (Dixon J) ('Stenhouse'); Australian Communist Party Case (1951) 83 CLR 1, 253 (Fullagar J).

62 Australian Communist Party Case (1951) 83 CLR 1, 253 (Fullagar J); George Winterton 'The Significance of the Communist Party Case' (1992) 18(3) Melbourne University Law Review 630; Roger Douglas 'Cold War Justice? Judicial Responses to Communists and Communism, 1945-1955' (2007) 29(1) Sydney Law Review 43.

63 Polyukhovich v Commonwealth (1991) 172 CLR 501, 592 (Brennan J); Susan Kiefel 'Judicial DecisionMaking in Times of War and Relative Peace' (2018) 92(9) Australian Law Journal 708, 714; Kate Chetty 'A History of the Defence Power: Its Uniqueness, Elasticity and Use in Limiting Rights' (2016) 16 Macquarie Law Journal 17; Kate Chetty, 'The Section 51(vi) Power in the Australian Constitution: Threats to Human Rights During the "War on Terror" and Suggested Remedies' (PhD Thesis, Charles Sturt University, August 2014) 182-214.

64 Farey (1916) 21 CLR 433, 441 (Griffith CJ), 452-3 (Isaacs J); Marcus Clark \& Co Ltd v Commonwealth (1952) 87 CLR 177, 218 (Dixon CJ), (McTiernan J agreeing at 225), 238 (Williams J) ('Marcus Clark'); Australian Communist Party Case (1951) 83 CLR 1, 195 (Dixon J), 227 (Williams J), 239 (Webb J).

65 Australian Communist Party Case (1951) 83 CLR 1, 253-5 (Fullagar J).

66 Hernan Pintos-Lopez and George Williams, "Enemies Foreign and Domestic": Thomas v Mowbray and the New Scope of the Defence Power' (2008) 28(1) University of Tasmania Law Review 83, 86. Ibid 104. 


\section{B Defence Power Cases Before Thomas v Mowbray}

Unsurprisingly, most cases involving the defence power have involved times when Australia was at 'war' ${ }^{68}$ In particular, the Commonwealth made extensive use of the power during and immediately after World War II, ${ }^{69}$ and to some extent World War I. ${ }^{70}$ A noteworthy feature of the High Court's response to these uses is general deference to Commonwealth decisions regarding the need for measures to assist war efforts. It reflects the legal maxim inter arma silent leges; that during times of war, the law is silent. Using this logic, though not in absolute terms, the High Court effectively permitted the Australian government significant control over key aspects of everyday life, including price controls over commodities, ${ }^{71}$ capital raising, ${ }^{72}$ production levels of particular goods, ${ }^{73}$ level of services, ${ }^{74}$ resolution of industrial disputes,${ }^{75}$ working conditions, ${ }^{76}$ rent control, ${ }^{77}$ administrative detention of individuals, ${ }^{78}$ and suppression of anti-war (and possibly, anti-Western) ${ }^{79}$ sentiment. ${ }^{80}$ The Commonwealth could demonstrate how regulation of these disparate features of Australian society was conducive to the war effort.

These cases create a perception that the defence power relates to hostility and armed conflict, and Australia's participation in such activity. The archetypal case of use of section 51(vi) has involved actual or near wartime, where there is active armed conflict between Australia and an external enemy. ${ }^{81}$ The language used by the justices in explaining the ambit of the power reflects that ${ }^{82}$ However, there

68 Thomas v Mowbray (2007) 233 CLR 307, 449 (Hayne J) ('Thomas').

69 Stenhouse (1944) 69 CLR 457; Marcus Clark (1952) 87 CLR 177; R v University of Sydney; Ex parte Drummond (1943) 67 CLR 95 ('Drummond'); Australian Woollen Mills Ltd v Commonwealth (1944) 69 CLR 476; Pidoto v State of Victoria (1943) 68 CLR 87 ('Pidoto').

70 Farey (1916) 21 CLR 433; Lloyd v Wallach (1915) 20 CLR 299 ('Lloyd').

$71 \quad$ Farey (1916) 21 CLR 433.

72 Marcus Clark (1952) 87 CLR 177.

73 Stenhouse (1944) 69 CLR 457.

74 Drummond (1943) 67 CLR 95.

75 Pidoto (1943) 68 CLR 87.

76 Victorian Chamber of Manufactures v Commonwealth (1943) 67 CLR 347.

77 Silk Bros Pty Ltd v State Electricity Commission of Victoria (1943) 67 CLR 1.

78 Lloyd (1915) 20 CLR 299.

$79 R v$ Sharkey (1949) 79 CLR 121, 160 (Williams J), 163 (Webb J) ('Sharkey'). While there is no discussion of section 51(vi) in this case, Heydon $\mathrm{J}$ stated that anti-sedition and subversion legislation of the kind considered in that case would be supported by the defence power, at least in terms of how it is interpreted today: Pape (2009) 238 CLR 1, 171 (Heydon J).

80 Sickerdick $v$ Ashton (1918) 25 CLR 506.

81 It must be acknowledged that the High Court has permitted its use during periods of 'war preparedness' and in the aftermath of war: Marcus Clark (1952) 87 CLR 177.

82 Griffith CJ has stated that 'the power to legislate with respect to defence extends to any law which may tend to the conservation or development of the resources of the Commonwealth so far as they can be directed to success in war': Farey (1916) 21 CLR 433, 441 (Griffith CJ). In the same case, Barton J spoke of the power in terms of fighting an actual or possible 'invasion' of the nation: at 447 , Isaacs J claimed that '[a]ctual defence ... comes only where we are at war': at 453, and Higgins J said that defence was 'primarily a matter of force': at 458; Marcus Clark (1952) 87 CLR 177, 218 (Dixon CJ), 226 (McTiernan J). Dixon J has also stated that 'the central purpose of the legislative power in respect of defence is the protection of the Commonwealth from external enemies and it necessarily receives its fullest application in times of war': Australian Communist Party Case (1951) 83 CLR 1, 194 (Dixon J). 
have been some exceptions where the power has been utilised against those living in Australia. In other words, internal threats. The defence power is not limited to times of actual war, and can include times of war preparedness, or the aftermath of war. Further, it has been suggested that the power might be used to deal with 'war or national emergency' 83 or 'state of emergency'.84 These sentiments indicate a possible broader conception of defence, beyond the archetypal situation of armed conflict, or preparedness for it.

It can include activity peripheral to core defence activity, particularly activity carried out to maintain capability and capacity in core activity. Most prominent here was Attorney-General for Victoria v Commonwealth, where a majority of the High Court determined a clothing factory established by the Commonwealth to make uniforms for defence personnel could legally make uniforms for non-defence officers, authorised by the defence power. This was on the basis the factory had idle capacity, and continuation of that type of work helped maintain the workforce's skills and expertise in particular areas. ${ }^{85}$

While usually the use of the defence power will be targeted at an external threat, members of the High Court have acknowledged the potential use of the power with respect to so-called 'internal' threats:

[I]t cannot, in my opinion, be doubted that there exists also a legislative power in the [Commonwealth] Parliament, which it is not easy to define in precise terms, to make laws for the protection of itself and the Constitution against domestic attack. ${ }^{86}$

The Court will carefully consider broad executive discretions in the defence context, where a lack of objective criteria for the exercise of the discretions essentially renders such exercise unreviewable. While it might permit such laws in wartime, ${ }^{87}$ it has frowned upon similar provisions at other times. ${ }^{88}$

The Court has accepted use of section 51(vi) to implement in-house defence disciplinary procedures like courts-martial, where structured along traditional lines. ${ }^{89}$ However, the Commonwealth must take care as to how these are structured, and where it significantly alters the powers of such bodies, or creates new bodies with broader powers than traditionally exercised in this field, for instance permitting them to make final and binding decisions, the High Court will declare them invalid. ${ }^{90}$ This is because such a structure is contrary to the separation of powers for which the Australian Constitution provides, involving a non-Chapter

83 Australian Communist Party Case (1951) 83 CLR 1, 255 (Fullagar J) (emphasis added). Fullagar J stated 'the existence of war or national emergency is recognized as bringing into play the secondary or extended aspect of the defence power': at 255.

84 Stenhouse (1944) 69 CLR 457, 471 (Dixon J).

85 A-G (Vic) v Commonwealth (1935) 52 CLR 533 ('Clothing Factory Case'). Cf Commonwealth v Australian Commonwealth Shipping Board (1926) 39 CLR 1.

86 Australian Communist Party Case (1951) 83 CLR 1, 259 (Fullagar J). See also Latham CJ's judgment: at 152; Burns v Ransley (1949) 79 CLR 101, 110 (Latham CJ) ('Burns').

87 Lloyd (1915) 20 CLR 299.

88 Australian Communist Party Case (1951) 83 CLR 1.

89 Re Tracey; Ex parte Ryan (1988) 166 CLR 518 ('Tracey’); Lane v Morrison (2009) 239 CLR 230, 251

(French CJ and Gummow J) ('Lane'). See for discussion James Stellios, 'Military Justice and the Constitution' in Creyke, Stephens and Sutherland (eds) (n 36).

90 Lane (2009) 239 CLR 230, 266 (Hayne, Heydon, Crennan, Kiefel and Bell JJ); Haskins v Commonwealth (2011) 244 CLR 22; Nicholas v Commonwealth (2011) 244 CLR 66. 
III court purporting to exercise federal judicial power, and is thus constitutionally invalid. ${ }^{91}$

\section{Thomas v Mowbray ('Thomas') $)^{92}$}

This case further tested the boundaries of section 51(vi). One reason was that, unlike the factual scenarios in most cases discussed above, there had been no declaration of 'war'. In relation to World Wars I and II, there had been a formal declaration of war to which Australia was a party. However, the tranche of national security legislation that followed 9/11 could not be traced to a declaration of 'war'. Of course, politicians had announced a 'war on terror'. However, this was rhetoric. A declaration of war was typically made against another nation(s). In the case of the 'war on terror', no declaration of war was possible, because the 'war' was not against any particular nation(s), but an ideology whose adherents spanned jurisdictions. The question for the Court was whether section 51(vi) extended to the making of laws in circumstances where no formal declaration of war existed, and where the 'conflict' did not involve specified sovereign states, but an ideology. The particular question concerned use of control orders against an individual that might assist in protecting the public from terrorist acts. In other words, a measure seeking to prevent possible future terrorism, not responding to past terrorist acts. By a majority of 5:2, the High Court validated the control order provisions of the Criminal Code 1995 (Cth), on the basis of section 51(vi). In so doing, members of the Court made significant observations about the scope and ambit of this power.

Gleeson CJ rejected suggestions of narrow limits on its scope. Specifically, he rejected suggestions that the power was limited to defending Australia against aggression from a foreign nation. ${ }^{93}$ Other justices agreed. ${ }^{94}$ Gleeson CJ rejected an argument that it was limited to external threats. ${ }^{95}$ This was particularly important, because the person challenging the validity of the provision was an Australian citizen living here. Gleeson CJ stated forcefully that the section 'is not confined to waging war in a conventional sense of combat between forces of nations ${ }^{96} \mathrm{He}$ also rejected suggestions that the power was limited to protecting

$91 \quad R$ v Kirby; Ex parte Boilermakers' Society of Australia (1956) 94 CLR 254 ('Boilermakers' Case').

92 (2007) 233 CLR 307. See for commentary Andrew Lynch 'Thomas v Mowbray: Australia's "War on Terror” Reaches the High Court' (2008) 32(3) Melbourne University Law Review 1182; Pintos-Lopez and Williams (n 66); Oscar I Roos, 'Alarmed, but Not Alert in the "War on Terror": The High Court, Thomas v Mowbray and the Defence Power' (2008) 15 James Cook University Law Review 169; Ben Saul, 'Terrorism as Crime or War: Militarising Crime and Disrupting the Constitutional Settlement?' (2008) 19(1) Public Law Review 20.

93 Thomas (2007) 233 CLR 307, 324 (Gleeson CJ).

94 Ibid 362 (Gummow and Crennan JJ), 395 (Kirby J), 457 (Hayne J).

95 Ibid 324 (Gleeson CJ, Gummow and Crennan JJ agreeing at 361, Kirby J agreeing at 395, Hayne J agreeing at 451, Callinan J agreeing at 503, Heydon J agreeing at 511).

96 Ibid 324 (Gleeson CJ). This position may be contrasted with the statement of Dixon J in Australian Communist Party Case (1951) 83 CLR 1, 195 (Dixon J) referring to conceptions of the use of the defence power in the past that until then 'have been generally regarded as appropriate only to a time of serious armed conflict'. 
bodies politic, as opposed to the individuals whom the body politic represented. ${ }^{97}$ Other justices agreed. ${ }^{98}$

Thus, the case heralded an expansion of the Commonwealth's legislative power under section 51(vi). ${ }^{99}$ Specifically, this was because it was held to permit the Commonwealth to legislate during a time when no official 'war' had been declared against any other nation, ${ }^{100}$ to take preventative rather than reactive measures to threats or perceived threats, and to deal with an internal rather than external threat. And it was not confined to threats to the body politic, as opposed to the people whom it represents.

\section{Possible Broader Application of the Power}

\section{Emergencies}

As broad as the decision in Thomas was, there were suggestions in it, and elsewhere, of broader possible horizons for engagement of the defence power. Gummow and Crennan JJ quoted, with evident approval, ${ }^{101}$ Alexander Hamilton, writing in The Federalist. ${ }^{102}$ Speaking of Congress' power over war, Hamilton stated that defence powers:

[O]ught to exist without limitation, because it is impossible to foresee or define the extent and variety of national exigencies, or the correspondent extent and variety of the means which may be necessary to satisfy them. The circumstances that endanger the safety of nations are infinite, and for this reason no constitutional shackles can wisely be imposed on the power to which the care of it is committed.

Kirby J, dissenting in the result, was alive to the possibly broader contours of section 51(vi). He observed presciently:

A question arises as to the extent to which such a power extends beyond the defence power. The Commonwealth argued that, in this case, where the suggested threat involved a 'very clear physical threat by human beings to cause damage', that fact could, if proved, fall within s 51(vi). It is unnecessary to decide whether a wider national protective power exists to defend the nation against others threats and dangers, for example pandemics, drought, social or even health issues. ${ }^{103}$

Extra-judicially, the current Chief Justice of the High Court noted the deference to which past decisions of the executive and legislature had been given during times of war. She suggested that it was possible the High Court might adopt a similar stance during periods of 'heightened danger and emergency':

Judges of our time have not had to face difficult questions as to whether the existence of extreme danger or emergency may warrant a different approach to legislative and executive power ... Nonetheless, the response of judges in earlier

97 Thomas (2007) 233 CLR 307, 324 (Gleeson CJ).

98 Ibid 362 (Gummow and Crennan JJ, Kirby J dissenting at 395).

99 Pintos-Lopez and Williams (n 66) 102.

100 Lee et al (n 11) 53.

101 Thomas (2007) 233 CLR 307, 360 (Gummow and Crennan JJ) quoting Alexander Hamilton, James Madison and John Jay, The Federalist, ed Benjamin Fletcher Wright (Harvard University Press, 1961) $199-200$.

102 Hamilton, Madison and Jay (n 101) 200 (emphasis omitted).

103 Thomas (2007) 233 CLR 307, 389 (Kirby J) (emphasis added) (citations omitted). Callinan J clearly took a narrower view, stating that the defence power concerned cases where the Australian people were 'at risk of danger by the application of force': at 504 . 
times, who have felt the weight of war, does not suggest that we should assume that a future response might be so much different. We cannot now know. ${ }^{104}$

Constitutional law expert George Williams, with Hernan Pintos-Lopez, has expressed the possibly even broader implications of the High Court's view of the defence power in Thomas, in terms of policing emergencies. ${ }^{105}$

\section{Action to Protect the Commonwealth and Commonwealth Interests in Times Other than a Conventional War}

There also appears comments in some judgments suggesting that the Australian Government has constitutional power to protect itself and its interests. It is not entirely clear whether the source of this power is section 51(vi), inherent nationhood power and/or section 61, or some other power. For example, Quick and Garran state:

If ... domestic violence within a State is of such a character as to interfere with the operations of the Federal Government, or with the rights and privileges of federal citizenship, the Federal Government may clearly, without a summons from the State, interfere to restore order. Thus, if a riot in a State interfered with the carriage of the federal mails, or with inter-state commerce, or with the right of an elector to record [their] vote at federal elections, the Federal Government could use all the force at its disposal, not to protect the State, but to protect itself. Were it otherwise, the Federal Government would be dependent on the Governments of the States for the effective exercise of its powers. ${ }^{106}$

Notably, each of the three examples Quick and Garran gave where the federal government could intervene, interference with federal mail, interference with interstate trade and commerce, and interference with voting, would involve possible breaches of federal legislation. This suggests that such intervention on the Commonwealth's behalf would be supported by section 51(vi), because the second limb refers to control of forces to 'execute and maintain the laws of the Commonwealth'. Clearly, the learned authors were not referring to section 119, which only permits Commonwealth action in cases of invasion of a state or where states have requested assistance from domestic violence. Former High Court Justice Sir Victor Windeyer indicated in a letter that the Commonwealth could use members of the Defence Force to '[safeguard] ... its interests'. ${ }^{107}$ Justice Hope also concluded that 'the Commonwealth government can use all the force at its disposal, which would include the Defence Force, to protect itself and its interests'. 108

104 Chief Justice Susan Kiefel, 'The High Court Justices and the Weight of War' (Speech, Samuel Griffith Society, 4 August 2018) 9.

105 Pintos-Lopez and Williams state that '[a]fter Thomas, it is now possible to empower policing laws under the first limb of the defence power': Pintos-Lopez and Williams (n 66) 104; and that 'it may also open the way for greater use of military forces for internal security purposes': at 110. See also Geoffrey Lindell 'The Scope of the Defence and Other Powers in the Light of Thomas v Mowbray' (2008) 10(3) Constitutional Law and Policy Review 42, 44, which refers to Thomas as reinforcing 'the relevance of the defence power for dealing with internal disturbances and disorder'. For criticism of this aspect of the decision, see Saul (n 92) 26-7. Quick and Garran (n 21) quoted with apparent approval in Sharkey (1949) 79 CLR 121, 151 (Dixon J).

107 Windeyer (n 21) [7].

108 Hope (n 21) 151. 
In conclusion, there is support for the suggestion that the Commonwealth's defence power includes response to emergencies, as well as action taken to protect Commonwealth interests.

\section{E Constitutionality of the Defence Act Provisions under the Defence Power}

It is necessary to apply our knowledge of the contours of the defence power to assess the validity of the relevant provisions of the Defence Act 1903 (Cth) discussed above.

The first argument is that section 33 of the Defence Act 1903 (Cth) applies where the Governor-General believes in a state of affairs that is likely to affect Commonwealth interests. As explained above, there is academic support for the proposition that section 51(vi) extends to permit action to protect Commonwealth interests. The second argument is that section 35 of the Defence Act 1903 (Cth) applies in cases of 'sudden and extraordinary emergency'. As noted above, there is both judicial and academic support for the application of section 51(vi) to situations of emergency.

Further, consider the course of interpretation of section 51(vi) since Federation. The trend has been towards interpreting the power broadly and extensively, particularly during times of tumult and trouble. This has been evident in the depth and breadth of the circumstances in which use of the power has been countenanced. So, for example, during the World Wars and for a period afterwards, this was reflected in the depth of the use of the power, to control a broad range of activity that could potentially affect the defence effort. Commonwealth regulation of activity could be deep in the way it impacted society. Subsequently, cases such as Thomas have indicated the breadth of the power, confirming that it could be utilised in times where no formal war has been declared, when the 'threat' was purely internal, and where there was no direct threat to the body politic. Thus, while not an absolute or unlimited power, the trend in the case law has been to recognise the depth and breadth of its scope.

Given these trends, it is not considered radical for the Commonwealth to argue the power should or could include response to national emergency caused by natural disaster, such as bushfires, or a pandemic. As articulated above, in Thomas, Kirby J openly canvassed such a possibility. Extra-judicially, Chief Justice Kiefel canvassed the possible use of the defence power during periods of 'extreme danger or emergency', as has Williams. Such a conclusion also draws support from statements alluded to above that the Commonwealth can act to protect itself and its interests. Though there is conjecture as to whether this relates to section 51(vi) or another head of power, it must be in the Commonwealth's interests to keep its subjects safe and well. From a social contract perspective, the most fundamental objective of any government is to protect members of its society. Individual members of that society cede certain rights and freedoms to their government; one thing they might legitimately expect in return is that government will protect them from harm as far as is reasonably possible. ${ }^{109}$ 
The third argument is based on the literal wording of section 51(vi). Nowhere in the section is it expressly confined to circumstances of an actual declared war between nations. It is similarly not expressly confined to situations involving armed conflict or violence. The words are of general nature, and the High Court has determined that the phrase 'naval and military defence of the Commonwealth' is not limiting. ${ }^{110}$

The fourth argument is based on the fact that the power is purposive, that laws are validly enacted under section 51(vi) when it can be demonstrated that they were enacted for a purpose of defending the nation. It could clearly be argued that the Commonwealth's efforts regarding the bushfire season of 2019-20 were directed to defending the nation. It is part of defending the nation to evacuate individuals from harm. Some have argued that the quantum of harm is relevant in determining whether section 51(vi) can be utilised. ${ }^{111}$ If this were accepted, the quantum of possible harm from these bushfires was high, with bushfires in three states and a territory covering hundreds of thousands of hectares of property, posing a direct threat to the lives and livelihoods of many. It could also be argued that the Commonwealth's response to the COVID-19 pandemic is an attempt to defend the nation from an insidious threat. Again, thousands of people have died from this virus overseas. In sum, the Commonwealth's emergency response in both cases has a purpose of defending the people of the nation, where the quantum of harm is significant.

For these four reasons, it is submitted that the Commonwealth has a strong constitutional argument under section 51(vi) to validate its response to the bushfire crisis and pandemic. Use of the military would be validated under relevant provisions of the Defence Act 1903 (Cth), including section 33 (though not actually utilised). Recall that this section deals with a government response where it is believed domestic violence will likely affect Commonwealth interests. COVID-19 has significantly affected Commonwealth interests, fundamentally so in terms of the health and safety of citizens. It has affected Commonwealth interests in terms of our relations with other nations, and Australia's financial situation, as the nation seeks to save as many jobs and businesses as possible, and provide financial support to those affected. Domestic violence could be interpreted broadly to include the kind of unrest and tumult with which the country has dealt recently. Further, it is possible that COVID-19 and/or the bushfires amount to the kind of 'sudden and extraordinary emergency' that would attract use of the power under section 51U(4)(a) of the Defence Act 1903 (Cth), given the scale of the health and economic crises. On the other hand, the government has had more time to deal with these situations than it would in the case, for example, of a sudden terrorism event. To some extent, Commonwealth involvement has been at the request and consent of the states, meaning that section 35 of the Defence Act 1903 (Cth) could potentially be engaged.

I turn to consider the constitutional validity of other Commonwealth action, not involving legislation, taken in response to the bushfire and COVID-19 crises.

110 Farey (1916) 21 CLR 433, 440 (Griffith CJ).

111 Saul (n 92) 27. 
A noteworthy feature of this action has been involvement of the ADF, but the discussion below has broader implications for Commonwealth power in the response to emergency situation, whether or not the military is used.

\section{SECTION 61 EXECUTIVE POWER, SECTION 51(XXXIX) INCIDENTAL POWER AND THE INHERENT NATIONHOOD POWER}

Whilst the existence of the first two is undoubted, doubt attends the contours of the suggested 'inherent nationhood power'. While some members of the High Court have suggested such an implied power does exist, which may be broader than section 61 and section 51(xxxix), ${ }^{112}$ others prefer to rely on the express terms of section 61 and section 51(xxxix), and what may fairly be said to be encompassed within them.

\section{A Development of These Powers}

This uncertainty is somewhat exacerbated by uncertainty as to the scope of the Commonwealth's executive power under section $61 .^{113}$ It is clearly expressed in sparse language, compared with the variety of topics expressed in section 51 regarding its legislative power, and has not been defined. ${ }^{114}$ This may have been deliberate, partly from confusion around the scope of Crown prerogative, and partly because of a felt need for flexibility in the exercise of such powers. ${ }^{115}$ This was noted by one founding father, Alfred Deakin. Deakin referred to the founding fathers' intention of a broad sphere of executive power which would be dangerous, if not impossible, to define, which flowed 'naturally ... from the nature of the Federal Government itself'. ${ }^{116}$ Sir Edward Mitchell stated in evidence to the Royal Commission on the Constitution (1929) that:

The executive government cannot be confined ... merely to those specific matters which come within the provisions enumerating what it is authorised to bring before Parliament to legislate about. It is clear that all sorts of emergencies may arise, and all sorts of things may happen as to which the executive government must have a free hand. ${ }^{117}$

112 The incidental power in section 51(xxxix) permits the Commonwealth to legislate 'in aid of an exercise of the executive power': Davis v Commonwealth (1988) 166 CLR 79, 95 (Mason CJ, Deane and Gaudron JJ) ('Davis'); the legislation validated in Pape (2009) 238 CLR 1 was an instance.

113 Moore, Crown and Sword (n 33) 8-9.

114 Davis (1988) 166 CLR 79, 92 (Mason CJ, Deane and Gaudron JJ).

115 Michael Crommelin, 'The Executive' in Gregory Craven (ed), The Convention Debates 1891-1898: Commentaries, Indices and Guide (Legal Books, 1986) vol 6, 127, 147.

116 Alfred Deakin, 'Channel of Communication with Imperial Government: Position of Consuls: Executive Power of Commonwealth' in Patrick Brazil and Bevan Mitchell (eds), Opinions of Attorneys-General of the Commonwealth of Australia (Australian Government Publishing Service, 1981) vol 1, 129, 130 ('Opinions'). Moore noted there is little in the convention debates concerning the executive power: Moore, Crown and Sword (n 33) 25.

117 Commonwealth, Report of the Royal Commission on the Constitution (Report, 1929), vol 2760. 
One view is that the Commonwealth's executive power was intended to be limited to the execution of Commonwealth laws enacted under one of its legislative powers, together with Crown prerogative powers, ${ }^{118}$ and powers conferred upon it by statute. ${ }^{119}$ One adherent to this view is former leading constitutional scholar George Winterton. ${ }^{120}$ Winterton conceived of the executive power in terms of both breadth and depth. He argued its breadth was defined by reference to the extent of Commonwealth legislative power. Breadth here referred to subject matter. Separately, its depth was informed by the extent of the Crown prerogative. It referred to what were considered to be within the ambit of such prerogatives. This interpretation finds support in the wording of section 61 itself, which refers to executive power extending to 'the execution and maintenance of the Constitution and laws of the Commonwealth'. It might be suggested that reference to the execution of the laws of the Commonwealth invites limiting of the executive power to subject matter within Commonwealth legislative power, and reference to execution and maintenance of the Constitution invites limiting of the executive power to what were traditionally within Crown prerogatives. ${ }^{121}$

One advantage of confining the 'depth' of the executive power in this way is that, if limited to crown prerogatives, its use would be subject to Parliament, because (the Commonwealth) Parliament can alter such prerogatives. In effect, this is important in preserving the primacy of the legislature over the executive. This is also important because the legislature is the body accountable to the people within a democratic structure. ${ }^{122}$ The dangers of executive overreach are known. ${ }^{123}$

Cameron Moore supports concentration on prerogative powers, particularly in the context of internal emergency, rather than a broader view:

The use of military power on such a questionable basis [referring to the use of the military to permit the safe internal travel of foreign dignitaries], especially internally, seems contrary to the principle of legality and the very spirit of constitutional government. ... the 'nationhood power', relying upon s 61 alone and 'absent authority supplied by statute', must only be a basis of last resort in

118 Peter Gerangelos 'The Executive Power of the Commonwealth of Australia: Section 61 of the Commonwealth Constitution, "Nationhood" and the Future of the Prerogative' (2012) 12(1) Oxford University Commonwealth Law Journal 97, 119; Leslie Zines 'The Inherent Executive Power of the Commonwealth' (2005) 16 Public Law Review 279, 281; Duncan Kerr 'The High Court and the Executive: Emerging Challenges to the Underlying Doctrines of Responsible Government and the Rule of Law' (2009) 28(2) University of Tasmania Law Review 145, 180.

119 On this aspect of executive power, see Janina Boughey and Lisa Burton Crawford (eds) Interpreting Executive Power (Federation Press, 2020).

120 George Winterton, 'The Limits and Use of Executive Power by Government' (2003) 31(3) Federal Law Review 421, 426; George Winterton, 'The Relationship Between Commonwealth Legislative and Executive Power' (2004) 25(1) Adelaide Law Review 21, 35-6.

121 Some still maintain this position: see, eg, Peta Stephenson, 'Nationhood and Section 61 of the Constitution' (2018) 43(2) University of Western Australia Law Review 149, 153.

122 See for elaboration George Winterton, Parliament, The Executive and the Governor-General: $A$ Constitutional Analysis (Melbourne University Press, 1983) 34.

123 Classically, in the Australian Communist Party Case (1951) 83 CLR 1, Dixon J stated that: '[h]istory, and not only ancient history, shows that in countries where democratic institutions have been unconstitutionally superseded, it has been done not seldom by those holding the executive power': at 187 . 
authorising action by the ADF. Such action must first find its basis in one of the previously recognised prerogatives. ${ }^{124}$

On the other hand, High Court authorities confirm the Commonwealth's executive power is not limited to those concepts falling within what has been known as the prerogative, ${ }^{125}$ and contains some implied power. This finds textual basis in the use of the phrase 'maintenance of this Constitution' in section $61 .{ }^{126}$ This is important, because elsewhere in the realm of constitutional implications, the Court has insisted that they have such basis in the text and structure of the Constitution. $^{127}$

A broader view would develop over time. The suggestion of an 'implied nationhood power' appeared in High Court decisions after World War II. Its genesis is Dixon $\mathrm{J}$ in $R v$ Sharkey, ${ }^{128}$ where he discusses a power to punish sedition that 'arises out of the very nature and existence of the Commonwealth as a political institution'. ${ }^{129}$ In its sister case Burns $v$ Ransley, ${ }^{130}$ Dixon J refers to an incidental Commonwealth power to deal with 'incitements to an antagonism to constitutional government'. ${ }^{131}$ Read together, these sentiments suggest Dixon J's concern with preservation of existing governmental and constitutional structure, and the legislative (not executive) power inhering in the Commonwealth to protect that structure, in terms of self-preservation. This is confirmed in Australian Communist Party v Commonwealth (the 'Australian Communist Party Case'), ${ }^{132}$ where Dixon $\mathrm{J}$ referred to the power to legislate against subversive conduct, as one example, having 'a source in principle that is deeper or wider than a series of combinations of the words of s 51(xxxix) with those of other constitutional powers'. ${ }^{133}$ On the previous page of the judgment, he stated the power of the Commonwealth to deal with subversion was not limited to such powers. ${ }^{134}$ He referred to it as an 'implied power' like that existing in the United States Congress. ${ }^{135}$

The suggestion that lawmakers have implied powers has historical support. In the $19^{\text {th }}$ century, the Privy Council, hearing appeals from then British colonies, considered possible implied or inherent legislative powers. These decisions typically occurred in the context of Parliament's power to punish for contempt. In that context, there are references to inherent legislative power based around the

Moore, Crown and Sword (n 33) 74-5.

125 Re Residential Tenancies Tribunal of New South Wales $v$ Henderson; Ex parte Defence Housing Authority (1997) 190 CLR 410, 442 (Dawson, Toohey and Gaudron JJ), 459 (McHugh J) ('Residential Tenancies'); Pape (2009) 238 CLR 1, 60 (French CJ), 83 (Gummow, Crennan and Bell JJ); CPCF v Minister for Immigration and Border Protection (2015) 255 CLR 514, 538 (French CJ) ('CPCF').

126 Pape (2009) 238 CLR 1, 83 (Gummow, Crennan and Bell JJ) (emphasis added); George Duke 'Popular Sovereignty and the Nationhood Power' (2017) 45(3) Federal Law Review 415, 429.

127 Lange v Australian Broadcasting Corporation (1997) 189 CLR 520, 560-1 (Brennan CJ, Dawson, Toohey, Gaudron, McHugh, Gummow and Kirby JJ) ('Lange'). Sharkey (1949) 79 CLR 121.

129 Ibid 148 (Dixon J).

130 Burns (1949) 79 CLR 101.

131 Ibid 116 (Dixon J).

132 (1951) 83 CLR 1.

133 Ibid 188 (Dixon J).

134 Ibid 187 (Dixon J).

135 Ibid 188 (Dixon J), 260 (Fullagar J). 
concept of 'necessity' and 'self-protection' of the body. ${ }^{136}$ Lord Selborne summarised these precedents in Barton v Taylor, concerning the powers of the NSW Parliament:

[No] powers ... are incident to or inherent in a Colonial Legislative Assembly (without express grant) except 'such as are necessary to the existence of such a body, and the proper exercise of the functions which it is intended to execute'. Whatever, in a reasonable sense, is necessary for these purposes, is impliedly granted whenever any such legislative body is established. ... protective and selfdefensive powers only, and not punitive, are necessary. ${ }^{137}$

These comments, around an inherent right to protection, also appear in the judgment of the High Court in Rv Kidman, ${ }^{138}$ although the context there concerned questions around executive power, ${ }^{139}$ not legislative power as with the Privy Council decisions. Cases would subsequently accept a wider view of the inherent nationhood power, as part of the executive power. In Victoria $v$ Commonwealth ('Australian Assistance Plan Case'), ${ }^{140}$ a broader view is apparent. Jacobs J classically stated:

The growth of national identity results in a corresponding growth in the area of activities which have an Australian rather than a local flavour. Thus, the complexity and values of a modern national society result in a need for co-ordination and integration of ways and means of planning for that complexity and reflecting those values. Inquiries on a national scale are necessary and likewise planning on a national scale must be carried out. Moreover, the complexity of society, with its various interrelated needs, requires co-ordination of services designed to meet those needs. $^{141}$

Mason J recognised an implied nationhood power sourced from section 61 and section 51(xxxix) to 'engage in enterprises and activities peculiarly adapted to the government of a nation and which cannot otherwise be carried on for the benefit of the nation', ${ }^{142}$ and 'engage in activities appropriate to a national government ${ }^{143}$ but cautioned it was limited, so as not to interfere with the constitutional division of powers between federal and state governments. As a result, the mere fact it was more convenient to formulate and administer policy at the national government was not, in his opinion, sufficient to attract constitutional power to the federal

136 Kielley v Carson (1842) 4 Moo PC 63, 88; 13 ER 225, 234 (Parke B, for Lords Lyndhurst, Brougham, Denman, Abinger, Cottenham, Campbell, Sir Lancelot Shadwell, Sir N C Tindal, Erskine J and Dr Lushington); Doyle v Falconer (1866) LR 1 PC 328, 339-40.

137 (1886) 11 App Cas 197, 203 (Lord Selborne for the Privy Council) (citations omitted).

138 (1915) 20 CLR 425.

139 Griffith CJ said that a 'right to protection' was an inherent attribute of sovereignty of the British monarch, and should be recognised in Australia: ibid 436 (Griffith CJ, Isaacs J agreeing at 440). (1975) 134 CLR 338 ('Australian Assistance Plan Case').

141 Ibid 412-13. Jacobs J linked these views with the prerogative: at 405-6. Jacobs J added that the power was not limited to areas over which the Commonwealth had legislative power: at 405 . Some argue that the comments of Mason and Jacobs JJ did not clearly express a view that the power had inherent content: Gerangelos (n 118) 116.

143 Ibid 398 (Mason J). See for criticism Anne Twomey 'Pushing the Boundaries of Executive Power: Pape, the Prerogative and Nationhood Powers' (2010) 34(1) Melbourne University Law Review 313, 333-4. 
government to enact it. ${ }^{144}$ Thus, the Australian Assistance Plan Case was significant in the current context in broadening, at least according to two High Court justices, the inherent nationhood power from a context of self-preservation, as appeared in the initial post-World War II decisions, to something broader, though a more precise elucidation of what the broader was would await later judgment. Further, Mason J placed the inherent nationhood power within section 61 executive power, whereas the earlier comments of Dixon J and the Privy Council decisions suggested this type of power we sometimes describe today as the inherent nationhood power was legislative, presumably sourced in section 51(xxxix) (in Australia). ${ }^{145}$

In Davis $v$ Commonwealth, ${ }^{146}$ the division between those justices who conceived of the inherent nationhood power as broader than the express powers such as section 61 and section 51(xxxix), and those who viewed it as being confined by those specific sections, crystallised. Mason CJ, Deane and Gaudron $\mathrm{JJ}$, and Brennan $\mathrm{J}$ took the former view; Wilson and Dawson JJ, and Toohey $\mathrm{J}$ the latter. $^{147}$

Mason CJ, Deane and Gaudron JJ stated that the Commonwealth had executive power to deal with matters 'within the peculiar province of the Commonwealth in its capacity as the national and federal government'. ${ }^{148}$ They added that the Commonwealth's legislative powers extended beyond those specifically conferred upon it, including those that could be implied by virtue of the Commonwealth's status as a polity. ${ }^{149}$ The power would be 'clearest' where the relevant Commonwealth actions did not really compete with state executive or legislative competence. ${ }^{150}$ Brennan $\mathrm{J}$ agreed with the formulation by Mason $\mathrm{J}$ in the Australian Assistance Plan Case that the executive power was affected by the practical ability of the states to engage effectively in the enterprise and 'the need for national action' ${ }^{151}$ He repeated with evident approval the comments of Mason $\mathrm{J}$ there that the executive power permitted the Commonwealth to engage in activities peculiarly adapted to the government of a nation, and which could

144 The only other judge to consider the matter, Barwick CJ, denied that the mere fact that a matter was of national interest or origin was sufficient to reach a conclusion the Commonwealth had constitutional power to legislate with respect to it: Australian Assistance Plan Case (1975) 134 CLR 338, 362 (Barwick CJ).

145 Some have questioned whether Mason and Jacobs JJ were simply referring to the common law prerogative, or intended something broader: Gerangelos (n 118) 116. Twomey (n 143) suggests Jacobs J was referring (only) to prerogative powers: at 330 .

146 (1988) 166 CLR 79.

147 This might have presaged a debate elsewhere in Australian constitutional law regarding whether implications from the Australian Constitution must be clearly sourced in its text and structure, or whether freestanding principles not closely sourced in its text and structure might be deduced. This debate occurred particularly in relation to the implied freedom of political communication. By the time of Lange (1997) 189 CLR 520, 566-7, the High Court in that context at least had reached the position that any constitutional implication had to be related to the express text and structure. 
otherwise not be carried on for its benefit. ${ }^{152}$ In agreeing with Jacobs $\mathrm{J}$ in that case, he referred to the nationhood power as encompassing 'protection and advancement of the Australian nation', ${ }^{153}$ and 'protection of the nation against forces which would weaken it'. ${ }^{154}$

The other justices adopted a narrower view, stating they did not support the existence of any 'implied nationhood power' beyond what was already contemplated by section 61 and section 51(xxxix) of the Constitution. ${ }^{155}$

In $R v$ Hughes, ${ }^{156}$ the High Court considered the section 61 power briefly, indicating agreement with an earlier statement of Mason $\mathrm{J}$ that the power related to the character and status of the Commonwealth as a national government. The Court added it was 'another matter' not requiring a decision whether the power enabled the Commonwealth to act merely because a matter was of national interest or concern. ${ }^{157}$

The question of the scope of these powers arose again during the Global Financial Crisis of 2008, where the federal government spent large amounts of money to keep Australia out of recession. The validity of the Commonwealth's measures was challenged. ${ }^{158}$ The federal government cited section 61, section 51 (xxxix) and/or the inherent nationhood power, among others, as heads of power to validate their actions. A majority of the High Court (French CJ, Gummow, Crennan and Bell JJ; Hayne, Heydon and Kiefel JJ dissenting) validated the federal measures under these heads of power.

French CJ reached his position based on the executive power, expressly declining to utilise the suggested inherent implied nationhood power. He stated that section 61 supported the initiatives because the measures taken 'were peculiarly within the capacity and resources of the Commonwealth Government'. ${ }^{159}$ This was similar to the language used by Mason $\mathrm{J}$ in the Australian Assistance Plan Case, although Mason J used that language to describe the inherent nationhood power.

The joint reasons of Gummow, Crennan and Bell $\mathrm{JJ}$ expressly adopted the position of Brennan $\mathrm{J}$ in Davis $v$ Commonwealth, the position which in turn had adopted the position of Mason $\mathrm{J}$ in the Australian Assistance Plan Case, that the executive power permitted the federal Parliament to engage in enterprises and activities peculiarly adapted to the government of a nation and which otherwise could not be carried on for its benefit. ${ }^{160}$ This did not mean merely something the Commonwealth considered to be of national interest and concern. ${ }^{161}$

Referring to the crisis in 2008, and whether it was the kind of circumstance met by the above test, the joint reasons continued:

Davis v Commonwealth (1988) 166 CLR 79, 111 (Brennan J).

Ibid 110 (Brennan J).

154 Ibid.

155 Ibid 103 (Wilson and Dawson JJ, Toohey J agreeing at 117).

156 (2000) 202 CLR 535

157 Ibid 555 (Gleeson CJ, Gaudron, McHugh, Gummow, Hayne and Callinan JJ).

158 Pape (2009) 238 CLR 1.

159 Ibid 63 (French CJ).

160 Ibid 87 (Gummow, Crennan and Bell JJ).

161 Ibid 88 (Gummow, Crennan and Bell JJ, Heydon J dissenting at 174). 
It can hardly be doubted that the current financial and economic crisis concerns Australia as a nation. Determining that there is the need for an immediate fiscal stimulus to the national economy in the circumstances set out above is somewhat analogous to determining a state of emergency in circumstances of a natural disaster. The Executive Government is the arm of government capable of and empowered to respond to a crisis be it war, natural disaster or a financial crisis on the scale here. ${ }^{162}$

Members of the High Court would subsequently confirm the possible applicability of the implied nationhood power to situations of 'emergency'. 163

While earlier case law suggested a close link between executive and legislative power, ${ }^{164}$ it was subsequently confirmed that the Commonwealth's executive power is not co-extensive with its legislative power. This works in both directions. Specifically, the executive power includes matters relating to the character and status of the Commonwealth as a national government, ${ }^{165}$ which is clearly broader than the heads of power enumerated in section 51, as well as including Crown prerogatives. ${ }^{166}$ Yet it is also narrower. A majority of the High Court in Williams determined the mere fact that the Commonwealth had legislative power to do a particular thing did not necessarily mean it had executive power over the same thing, ${ }^{167}$ although the meaning and contours of this limit remain unclear.

The Court in Williams [No 2] rejected the possibility that the executive power extended to anything the Commonwealth considered to be of national benefit or concern, ${ }^{168}$ a question left open in $R v$ Hughes. It also emphasised that it should

162 Ibid 89 (Gummow, Crennan and Bell JJ); in contrast, the dissentients stated that the mere fact that some described a situation as a 'crisis' or 'emergency' was insufficient, in itself, to reach a conclusion that section 61 supported a measure, otherwise the Commonwealth could effectively itself determine whether it had power in particular circumstances: at 123 (Hayne and Kiefel JJ). Hayne and Kiefel JJ did accept an implied legislative power flowing from the existence of the national polity: at 125 , but did not validate the challenged measures on that basis.

163 CPCF (2015) 255 CLR 514, 568 (Hayne and Bell JJ), 596 (Kiefel J).

164 Australian Assistance Plan Case (1975) 134 CLR 338, 362 (Barwick CJ) (though he noted unspecified exceptions to this general position), 379 (Gibbs J), 396 (Mason J). Deakin stated that 'the Commonwealth has executive power ... with respect to every matter to which its legislative power extends': Opinions (n 116) 131; See also Winterton (n 122) 30 stating that 'the contours of executive power generally follow those of the legislative power'; and Twomey (n 143) 321: '[i]t has generally been accepted that executive power follows legislative power'.

165 Williams [No 1] (2012) 248 CLR 156, 189 (French CJ).

166 Cadia Holdings Pty Ltd v New South Wales (2010) 242 CLR 195, 226 (Gummow, Hayne, Heydon and Crennan JJ); Williams [No 1] (2012) 248 CLR 156, 370 (Kiefel J). In that case, Kiefel J maintained the position that the executive power includes 'enterprises and activities peculiarly adapted to the government of the nation and which could not otherwise be carried out for the benefit of the nation': at 370 quoting Australian Assistance Plan Case (1975) 134 CLR 338, 772 (Mason J).

167 Williams (No 1) (2012) 248 CLR 156, 189 (French CJ), 232 (Gummow and Bell JJ), 249 (Hayne J). Cf Heydon J at 296, Kiefel J at 373. Crennan J did not specifically address this point. The main thrust of the Williams [No 1] decision, that the Commonwealth cannot generally contract in the absence of statutory authority, is not of direct relevance in the current context. See for discussion Shipra Chordia, Andrew Lynch and George Williams, 'Williams v Commonwealth: Commonwealth Executive Power and Australian Federalism’ (2013) 37(1) Melbourne University Law Review 189.

168 Williams v Commonwealth [No 2] (2014) 252 CLR 416, 466 (French CJ, Hayne, Kiefel, Bell and Keane JJ) ('Williams [No 2]'). See for discussion Chordia, Lynch and Williams (n 167). 
not be assumed the executive power of the Commonwealth is the same as that in the United Kingdom. ${ }^{169}$

\section{B Application of these Views to the Current Commonwealth Response to Bushfires and COVID-19 ${ }^{170}$}

\section{Section 61 Confined in Terms of Breadth to Subjects of Commonwealth Legislative Powers and in Terms of Depth to What Was Traditionally Considered to be within Crown Prerogatives}

If this view were taken, the Commonwealth's executive action in relation to the bushfire response and response to COVID-19 could piggyback on the Commonwealth's legislative action in this space. As discussed above, this would be premised on the section 51(vi) defence power. It is not entirely clear whether it would be necessary that the Commonwealth had in fact passed legislation under section 51(vi), in order to engage executive power under section $61,{ }^{171}$ or whether the fact it had the constitutional potential to do so was sufficient to attract executive power under section $61 .^{172}$ A majority of the Court in Williams favoured the former view. ${ }^{173}$

That the Commonwealth's executive power might be connected with its legislative power is consistent with the obiter statement of Kiefel $\mathrm{J}$ in $C P C F v$ Minister for Immigration and Border Protection:

It can hardly be said that a statute such as the [Maritime Powers] Act, which authorises a decision that the relevant powers be exercised in a particular way and details the manner and conditions of their exercise, and in respect of which the role of the Commonwealth Executive is discernible, supports an intention that the

169 Williams [No 2] (2014) 252 CLR 416, 469 (French CJ, Hayne, Kiefel, Bell and Keane JJ); Robert French 'Executive Power in Australia: Nurtured and Bound in Anxiety' (2018) 43(2) University of Western Australia Law Review 16, 32. Cf Twomey (writing prior to Williams [No 2]) stating that 'it would seem unlikely that s 61 was intended to confer greater executive power on the Commonwealth than was held by the United Kingdom government' (n 143) 317. This position is likely not that which was intended by the founding fathers: Gabrielle Appleby and Stephen McDonald 'Looking at the Executive Power through the High Court's New Spectacles' (2013) 35(2) Sydney Law Review 253, 272. Of course, the question of the relevance of the founding fathers' intention to current constitutional interpretation is a matter of strong debate, with examples of the High Court minimalising the importance of such intentions: New South Wales $v$ Commonwealth (2006) 229 CLR 1, 97 (Gleeson CJ, Gummow, Hayne, Heydon and Crennan JJ), but also with examples of their use: Cole v Whitfield (1988) 165 CLR 360, 388-91 (Mason CJ, Wilson, Brennan, Deane, Dawson, Toohey and Gaudron JJ) ('Cole').

170 Though the article is based primarily on the question of the use of military power during an emergency, this Part will offer some more general discussion about the possible application of the executive power in the circumstances of the federal government's response to the COVID-19 and bushfire emergency, including, but not limited to, its use of members of the Defence Force to implement its decisions.

171 Martin H Redish stated that "the executive branch is, in the exercise of its "executive" power, confined to the development of means for enforcing legislation already in existence': Martin H Redish, The Constitution as Political Structure (Oxford University Press, 1995) 117.

172 Australian Assistance Plan Case (1975) 134 CLR 338, 362 (Barwick CJ), 379 (Gibbs J), 396 (Mason J); Ruddock v Vadarlis (2001) 110 FCR 491, 543 ('Ruddock').

173 Williams [No 1] (2012) 248 CLR 156, 205 (French CJ, Gummow and Bell JJ agreeing at 234, Crennan J agreeing at 348); Chordia, Lynch and Williams (n 167) 191. 
Commonwealth Executive is to retain a complete discretion as to how such powers are to be exercised. ${ }^{174}$

In terms of depth, there is ample authority that the Crown prerogative includes significant aspects of warfare, including control of the armed forces. It has also been held to be engaged during periods of 'emergency'. Prior to noting the sources, it should first be acknowledged that they are English. This is important, because there has been a suggestion that the scope of executive power in the United Kingdom is not the same as that in Australia. This is conceded, but it is noted that the context in which these statements are made is the idea the power in the Australian context may be broader than that evident in the United Kingdom. ${ }^{175}$

In the leading House of Lords decision of Burmah Oil Co Ltd $v$ Lord Advocate, ${ }^{176}$ Lord Reid spoke of the Crown prerogative being engaged during times of 'extreme emergency', 'urgent necessity to take extreme steps' to protect the country, and 'sudden and extreme emergency placing public safety in peril' ${ }^{177}$ Viscount Radcliffe referred to the possibility that '[r]iot, pestilence and conflagration' might attract an exercise of prerogative power. ${ }^{178} \mathrm{He}$ held that the power was not limited to administering existing law, but extended to acting for the public good. ${ }^{179}$ In that conclusion, he drew upon Locke's Second Treatise of Government. Locke's social contract view of government led him to believe the power of the executive was unlimited. This was because citizens had ceded rights to their government, on the understanding the government would use its powers for the public good. However, it was impossible to foresee every power that a government would need, in order to do the public good. Locke thought this made it essential that the executive power be virtually unlimited in nature. ${ }^{180}$ Lord Hodson quoted with approval another decision describing the power in terms of national emergency, an urgent necessity for taking extreme steps to protect the

174 CPFC (2015) 255 CLR 514, 601 (Kiefel J dissenting). Referring to the comments of Kiefel J (as her Honour then was), David Letts and Rob McLaughlin conclude that 'the comment of Kiefel J foreshadows a line of reasoning which, if adopted in the future, could call into question the constitutional validity of authorising the use of the ADF in Australia relying on the executive power as an adjunct to an existing statutory scheme': Letts and McLaughlin (n 51) 116.

175 ' $[\mathrm{T}]$ here appears no good reason to treat the executive power recognised in s 61 of the Constitution as being, in matters of the raising and expenditure of public moneys, any less than that of the executive of the United Kingdom': Pape (2009) 238 CLR 1, 85 (Gummow, Crennan and Bell JJ) (emphasis added); cf Moore, Crown and Sword (n 33) 37: 'English authorities and legal history are important to understanding executive power but within a context in which the Commonwealth has more limited powers than the Crown in England'.

176 [1965] AC 75.

177 Ibid 101-6 (Lord Reid).

178 Ibid 115 (Viscount Radcliffe).

179 Ibid 118 (Viscount Radcliffe).

180 Locke stated ' $[\mathrm{m}]$ any things there are, which the Law can by no means provide for, and those must necessarily be left to the discretion of him (sic), that has the Executive power in his hands, to be ordered by him, as the publick (sic) good and advantage shall require' (n 109) 392-3. George Duke, quoting the maxim salus populi suprema lex esto (the welfare of the people should be the supreme law), concludes '[t]hese arguments suggest it would be an exaggeration to regard the project of grounding the nationhood power in popular sovereignty as incoherent. The right of a people to self-determination in pursuing their own conception of the public good can provide normative support for empowering the executive to act in circumstances unamenable to legislative authorisation': Duke (n 126) 438. 
nation. ${ }^{181}$ Lord Pearce referred to acts necessary to govern and protect citizens. ${ }^{182}$ Lord Upjohn said that it included whatever steps were necessary to protect the state. $^{183}$

Subsequent case law has confirmed this broad view. In $R v$ Secretary of State for the Home Department; Ex parte Northumbria Police Authority, ${ }^{184}$ the Court of Appeal recognised a prerogative around maintenance of the peace ${ }^{185}$ and/or acting for the common good. ${ }^{186}$ It includes protection of members of the community from danger to themselves personally and to their property. ${ }^{187}$ It confirmed its existence during times of 'national emergency'. ${ }^{188}$ Arthur Berriedale Keith's The Constitution of England from Queen Victoria to George VI lists seven chief powers of the executive, including the prerogative. These include the obligation to secure the country from aggression, and to preserve internal order. ${ }^{189}$ It is acknowledged that there is little case law on the precise content of the war prerogative. ${ }^{190}$

Of course, the content of the crown prerogatives is not immutable, and they are subject to statutory regulation, refinement or abolition, ${ }^{191}$ although a state law could not alter commonwealth prerogatives in Australia. ${ }^{192}$

These broad statements of the extent of the prerogative in emergency situations are ample to support the argument that section 61 would support the Commonwealth's responses to the bushfire crisis and COVID-19, including use of the military. These are measures taken to protect citizens and for the public good. Viscount Radcliffe specifically mentioned 'conflagration' and 'pestilence' in his list of subject matter included within the prerogative power. If the prerogative can

181 Burmah Oil Company Ltd v Lord Advocate [1965] AC 75, 136 (Lord Hodson), quoting Crown of Leon (Owners) v Admiralty Commissioners [1921] 1 KB 590, 603-4 (Reading CJ).

182 Ibid 148 (Lord Pearce).

183 Burmah Oil Company Ltd v Lord Advocate [1965] AC 75, 166 (Lord Upjohn). It is for a court to determine the ambit of the prerogative: $R$ (Miller) $v$ Prime Minister [2019] UKSC 41, [32] (Lady Hale and Lord Reed for the Court) ('Miller').

184 [1989] 1 QB 26.

185 Ibid 42 (Croom-Johnson LJ, Purchas LJ agreeing at 55, Nourse LJ agreeing at 58).

186 Ibid 58 (Nourse LJ).

187 Ibid 56-57 (Nourse LJ).

188 Ibid 51 (Purchas LJ).

189 Arthur Berriedale Keith, The Constitution of England from Queen Victoria to George VI (Macmillan and Co Ltd, 1940) vol 2, 44-5, quoted with approval in KM Hayne, 'Executive Power' (2017) 28(3) Public Law Review 236, 243. HV Evatt referred to three categories, including (a) executive powers to do certain things, such as declare war, make peace, pardon offenders; (b) immunities and preferences, for instance in relation to debts, or the application of laws; and (c) proprietary rights over land and things found on land: HV Evatt, The Royal Prerogative (Law Book Company, 1987) 30-1; Federal Commissioner of Taxation v Official Liquidator of EO Farley Ltd (in liq) (1940) 63 CLR 278, 320-1 (Evatt J) ('Farley').

190 Cameron Moore, 'Military Law and Executive Power' in Robin Creyke, Dale Stephens and Peter Sutherland (eds), Military Law in Australia (Federation Press, 2019) 75.

191 Residential Tenancies (1997) 190 CLR 410, 438 (Dawson, Toohey and Gaudron JJ); Miller [2019] UKSC 41, [41] (Lady Hale and Lord Reed for the Court); CPCF (2015) 255 CLR 514, 600 (Kiefel J); Peta Stephenson 'Statutory Displacement of the Prerogative in Australia' in Janina Boughey and Lisa Burton Crawford (eds), Interpreting Executive Power (Federation Press, 2020); Moore, 'Military Law and Executive Power' (n 190) 73; Moore, Crown and Sword (n 33) 54-7.

192 Residential Tenancies (1997) 190 CLR 410, 424 (Brennan CJ, Dawson, Toohey and Gaudron JJ agreeing at 438-9). A list of categories of Crown prerogatives appears in Farley (1940) 63 CLR 278, 320-1 (Evatt J). 
be extended to include economic action taken during a financial emergency that seriously threatens the nation, ${ }^{193}$ logic would suggest it could be extended to action taken to stop or slow the spread of disease during a deadly, worldwide pandemic threatening Australia, or deal with large-scale bushfire threats.

Moore opines the use of prerogative power to restore internal security is uncertain, but the notion of 'necessity' might support the use of prerogative power to authorise defence personnel cordoning areas off, searching particular premises, and working at vehicle checkpoints. ${ }^{194} \mathrm{HE}$ Renfree held that preservation of public safety was within the prerogative power. ${ }^{195}$ Similarly, Eburn, Moore and Gissing conclude:

$[T]$ he case law identifies that the source of the prerogative power is to protect the political entity (which includes the effective existence of the states) and its citizens from threat and danger, and is not expressly limited to the dangers posed by enemies in war. It must also follow, as a matter of practical reality, that when an overwhelming disaster strikes a state, regardless of its cause, the executive government must have power to respond to that disaster. ${ }^{196}$

Thus, even if the view were to be accepted that the executive power is confined in depth to those matters within the prerogative, there is a strong argument that section 61 would encompass the federal government's responses to the bushfire situation and COVID-19, as responses to clear national emergencies.

One practical advantage for the Commonwealth in relying on the prerogative aspect of its executive power is that this aspect might support measures that interfere with the rights of others, ${ }^{197}$ while reliance on the non-prerogative aspects of the executive power would (or may) ${ }^{198}$ not. ${ }^{199}$ In contrast, it seems legislation, for example supported by section 51(xxxix), may be coercive. ${ }^{200}$

193 Gerangelos (n 118) 121.

194 Moore, Crown and Sword (n 33) 187-8.

195 HE Renfree, The Executive Power of the Commonwealth of Australia (Legal Books, 1984) 466.

196 Eburn, Moore and Gissing (n 10) 11. They add ' $\mathrm{t}$ ] he need for national action in the face of a disaster that requires coordinated national assets or has effects across more than one state and/or territory suggests that the Commonwealth, by virtue of its position as the national government, has the necessary power to move into areas normally the responsibility of the states, and in extreme cases could exercise legislative authority if required': at 12 . They further note that 'the "executive power of the Commonwealth", [is] an inadequate foundation of uncertain strength that may be insufficient to deal with the forces unleashed during a catastrophic natural disaster. This should only be an option of last resort': at 23.

197 Plaintiff M68/2015 v Minister for Immigration and Border Protection (2016) 257 CLR 42, 98 (Gageler J) ('Plaintiff M68/2015').

198 Moore concluded that 'as much as [Ruddock $v$ Vadarlis] stands for a coercive use of nationhood power ... it is not widely supported in the case law or the literature and must be treated with some caution': Moore, Crown and Sword (n 33) 67.

199 Chu Kheng Lim v Minister for Immigration, Local Government and Ethnic Affairs (1992) 176 CLR 1, 19 (Brennan, Deane and Dawson JJ, Mason CJ agreeing at 10); Plaintiff M68/2015 (2016) 257 CLR 42, 105 (Gageler J); CPCF (2015) 255 CLR 514, 567 (Hayne and Bell JJ), 598 (Kiefel J). Cf Ruddock (2001) 110 FCR 491.

200 Davis (1988) 166 CLR 79, 99 (Mason CJ, Deane and Gaudron JJ), though a law based on section 51(xxxix) could not permit detention of an individual under the executive power, because such a law could not be described as 'incidental' when it purported to alter a fundamental aspect of the executive power: Plaintiff M68/2015 (2016) 257 CLR 42, 106 (Gageler J). Twomey concludes it is 'doubtful' whether section 51(xxxix) could be utilised as a basis for coercive action: (n 143) 326. However, as she 
It should be acknowledged that there is an argument in the academic literature that the existence of a statute on a particular subject matter may preclude exercise of the prerogative in that field. This is an argument developed by Moore. ${ }^{201} \mathrm{He}$ uses the 'covering the field' principle - that where a statute is clearly intended to 'cover the field', the prerogative that might otherwise have existed in that 'field' is extinguished, with one important exception. This is that if the federal government could show that the exercise of the executive power was 'necessary', then exceptionally its use might be justified. This is an interesting view, but has not (at least yet) commanded acceptance in courts. ${ }^{202}$ In any event, it is not submitted that the defence legislation discussed above reflects an intention that it 'cover the field' of defence personnel involvement in internal matters, ${ }^{203}$ though Letts and McLaughlin have alluded to possible challenge on this basis. ${ }^{204}$ In any event, the concept of 'necessity' here might overlap to some extent with the concept as discussed in the following two sub-sections.

\section{Section 61 Permits Commonwealth to Do Things Consistently with the Character and Status of National Government}

Though the precise meaning of this concept is somewhat elusive, and has been criticised on the basis of its subjectivity, ${ }^{205}$ it is supported by judgments of Dixon $\mathrm{J}$ in Burns $v$ Ransley and the Australian Communist Party case (though the comments may have referred to legislative, not executive, power), and Mason J in the Australian Assistance Plan Case. Mason J's sentiments in that respect were approved in the joint reasons in Hughes.

It is considered within the purview of national government to evacuate individuals on a large-scale during times of impending disaster, as occurred during the bushfire crisis. It is considered within the purview of a national government to enforce restrictions on movement of citizens between states and territories, and assist in enforcing restrictions on quarantine, to the extent these are not already supported by section 51(ix) of the Constitution. The COVID-19 situation is a national emergency. National decisions are being taken (with the input and support of state and territory governments). A (largely) national response is expected. It must be within the purview of a national government to take measures to safeguard

acknowledges, section 51(xxxix) has been used to create offences regarding section 96 grants, which is clearly coercive: ICM Agriculture Pty Ltd v Commonwealth (2009) 240 CLR 140, 166 (French CJ, Gummow and Crennan JJ).

Moore, Crown and Sword (n 33) 57-9. Ruddock (2001) 110 FCR 491.

203 It would be difficult to make this argument given section 51ZD of the Defence Act 1903 (Cth). Writing of its predecessor, section $51 \mathrm{Y}$, Moore notes that '[t]his section would appear to preserve prerogative powers with respect to control and disposition of the forces': Moore, Crown and Sword (n 33) 174.

204 Letts and McLaughlin suggest that a constitutional challenge could be 'mounted on the basis ... that pt IIIAAA of the Defence Act already provides a comprehensive regime for the use of the ADF in Australia and this has therefore extinguished any residual s 61 executive power. Although these situations are untested, an element of caution should be adopted if there is any future desire to use s 61 as a basis for the deployment of the ADF': Letts and McLaughlin, 'Military Aid to the Civil Power' (n 51) 66-7. They conclude that 'using s 61 alone to provide the legal basis for the use of the ADF within Australia is problematic from a legal perspective on a number of fronts': at 66 . 
the health of the Australian people, at least during an emergency. There is a strong view that the prime function of government is to safeguard its people. One of the two main reasons for the formation of the Commonwealth of Australia was the need to safeguard citizens of the colonies. ${ }^{206}$ Use of the military in such a context is unusual, ${ }^{207}$ but not unprecedented. ${ }^{208}$ Former High Court Justice Sir Victor Windeyer extra-judicially supported use of section 61 to call out the military, in the context of the so-called Bowral incident during the Commonwealth Heads of Government Meeting, where the military was used to secure safe passage of dignitaries from Sydney to Bowral. ${ }^{209}$ It should be conceded, however, that no High Court authority currently confirms the constitutional validity of use of the nationhood power in such a context. Thus experts urge 'conservative' and 'cautious' use of the power in this context. ${ }^{210}$

There is considered criticism of the use of concepts of 'emergency' and 'crisis', on the basis that they are not criteria by which the constitutionality of federal government action is to be judged, ${ }^{211}$ and with concern evident the federal government might abuse this power by declaring 'emergencies' which are not in fact such, to garner power which is effectively unreviewable. ${ }^{212}$ This is part of a broader concern expressed by Moore in this context that exercise of executive power must remain subject to rule of law. ${ }^{213}$

206 Patrick Parkinson, Tradition and Change in Australian Law (Thomson Reuters, $5^{\text {th }}$ ed, 2013) 156.

207 Mason CJ Wilson and Dawson JJ stated 'it is not the ordinary function of the armed services to "execute and maintain" the laws of the Commonwealth': Tracey (1988) 166 CLR 518, 540.

208 Moore, Crown and Sword (n 33) 64, 193-6. This is a reference to the so-called Bowral call out. Though the use of the military in this matter was not challenged in court, two members of the judiciary (Justice Hope of the New South Wales Supreme Court and Court of Appeal, and Sir Victor Windeyer of the High Court of Australia) expressed a view that the use of the military in such circumstances was a valid exercise of the executive power (n 21) 150 and [7] respectively.

209 The power of the Commonwealth Government to use the armed Forces at its command to prevent or suppress disorder that might subvert its lawful authority arises fundamentally ... because the Constitution created a sovereign body politic with the attributes that are inherent in such a body. The Commonwealth of Australia is not only a federation of States. It is a nation. ... [t] he ultimate constitutional authority for the calling out of the Defence Force ... was thus the power and the duty of the Commonwealth Government to protect the national interest and to uphold the laws of the Commonwealth.

Windeyer (n 21) 279-80 [6], [8].

210 Moore calls it 'arguable at best': Moore, Crown and Sword (n 33) 198. He suggests that the Commonwealth heed the suggestion of French CJ in Pape that the power in such a case might be utilised 'conservatively': at 203. Letts and McLaughlin note 'an element of caution should be adopted if there is any further desire to use s 61 as the basis for the deployment of the ADF': Letts and McLaughlin, 'Military Aid to the Civil Power' (n 51) 67.

211 Pape (2009) 238 CLR 1, 122 (Hayne and Kiefel JJ dissenting), 193 (Heydon J dissenting).

212 Twomey (n 143) 318-19. Michael Head refers to the 'innate difficulties' in doing so: Head, 'Another Expansion of Military Call Out Powers in Australia: Some Critical Legal, Constitutional and Political Questions' (n 25) 13; Michael Head, Calling Out the Troops: The Australian Military and Civil Unrest: The Legal and Constitutional Issues (Federation Press, 2009) 49-55.

213 Moore concludes that the principle of legality ... assumes that the executive can only act in accordance with the law. For this reason the resort to extraordinary executive powers needs to be part of the law, and not outside of it. An executive power with identified limits, even if they are not precise, is better than no power at all': Moore, Crown and Sword (n 33) 22; David Dyzenhaus argues that 'a liberal democratic state must adopt a liberal-legalist approach to emergencies, one which requires not only that all executive 
On the other hand, existing state legislation defines an 'emergency"214 and there is no suggestion that the power of decision-makers such as premiers to issue declarations of emergency ${ }^{215}$ is immune from judicial review. Of course, executive action typically is subject to judicial review, ${ }^{216}$ confirmed in the Australian Communist Party decision (where the Court reviewed a decision of the GovernorGeneral) and relevant legislation, ${ }^{217}$ including exercise of prerogative power. ${ }^{218}$ Contrary to the view expressed in the previous paragraph regarding nonreviewability, David Cole states:

[J]udicial review of emergency and national-security measures can and has established important constraints on the exercise of emergency powers and has restricted the scope of what is acceptable in future emergencies. ${ }^{219}$

An example of a review of an emergency declaration in Australia is Wotton $v$ Queensland [No 5]. ${ }^{220}$ There the applicant successfully challenged an emergency declaration on the basis that part of what occurred did not fall within the definition of an emergency under the Act as then drafted. ${ }^{221}$ This, together with the Australian Communist Party decision, demonstrate it is possible to challenge the validity of an emergency declaration. Courts will employ traditional methods of statutory interpretation like the presumption that statute is not intended to infringe fundamental civil rights except where stated clearly, and where more than one interpretation of a statutory provision, the court will prefer the one less invasive of human rights. ${ }^{222}$

Of course, the recent United Kingdom Supreme Court decision in $R$ (Miller) $v$ Prime Minister confirms availability of judicial review in relation to exercises of the prerogative. ${ }^{223}$

If the recent events involving the bushfires and the COVID-19 crisis can be seen as examples of 'civil disorder', the words of Leslie Zines are apposite:

action can be authorized by law, but also that all executive action is subject to the control of the rule of law': David Dyzenhaus 'Emergency, Liberalism and the State' (2011) 9(1) Perspectives on Politics 69, 70.

214 See, eg, State Emergency and Rescue Management Act 1989 (NSW) s 4.

215 See, eg, ibid s 33.

216 Andrew Hanna argues that executive action under section 61 should not be justiciable: Andrew Hanna, 'Nationhood Power and Judicial Review: A Bridge Too Far?' (2015) 39(2) University of Western Australia Law Review 327.

217 Administrative Decisions (Judicial Review) Act 1977 (Cth) s 3 (definition of 'decision to which this Act applies'). Though, note exceptions in relation to biosecurity: Administrative Decisions (Judicial Review) Regulations 2017 (Cth) regs 6(h)-(j).

$218 R$ v Toohey; Ex parte Northern Land Council (1981) 151 CLR 170, 218 (Mason J); Case of Proclamations (1611) 12 Co Rep 74, 76; 77 ER 1352, 1354; Chris Horan, 'Judicial Review of NonStatutory Executive Powers' (2003) 31(3) Federal Law Review 551.

219 David Cole, 'Judging the Next Emergency: Judicial Review and Individual Rights in Times of Crisis' (2003) 101(8) Michigan Law Review 2565, 2566.

220 [2016] FCA 1457.

221 Ibid [1139] (Mortimer J). Lee et al state that 'Mortimer J's approach treats a decision to declare a state of emergency as something that is justiciable': Lee et al (n 11) 193.

222 Potter v Minahan (1908) 7 CLR 277, 304 (O’Connor J).

223 Miller [2019] UKSC 41, [30]-[35] (Lady Hale and Lord Reed for the Court). See for discussion Moore, 'Military Law and Executive Power' (n 190) 70. 
It is difficult to envisage a situation of civil disorder today where some of the manifold interests and institutions of the Commonwealth would not be threatened or endangered. It would be a rare situation where the Commonwealth could not send the army or other force to deal with it on its own initiative and without requiring a formal application from the State government. ${ }^{224}$

The High Court has voiced concerns over the potential ambit of the executive power where its use threatens to undercut delineated constitutional responsibilities between the federal and state governments. Particularly in situations involving COVID-19, this concern is muted, given that the most significant decisions about a government response to the crisis are being taken by the National Cabinet, in which sit all state and territory leaders. Further, it is not suggested that the mere fact that national regulation of a particular matter is 'convenient' would be sufficient to attract the power. ${ }^{225}$

To the extent that the scope of executive power depends on the existence of legislative power, as Winterton suggests (part of his 'breadth' consideration), sections 51(ix), (vi) and (xxxix) provide it. However, this may not matter, given the High Court's current view that the legislative powers do not shape the contours of the executive power, ${ }^{226}$ unless the Commonwealth wishes to enact coercive measures, as explained above.

Here it is argued that it is within the character and status of a national government to protect the country from a deadly global pandemic and large-scale bushfire event. These are whole-of-country issues, requiring a whole-of-country response. It is not simply convenient for this to occur; it is essential that it occurred, and is occurring. Quite apart from the fiscal response to the COVID-19 crisis, which is appropriate for the federal government to co-ordinate given it is the only government with access to resources required, the national government has an essential role in co-ordinating the kind of decision-making going on in relation to the crisis, and co-ordination of the implementation of what has been agreed, in close relationship with the states/territories. This includes use of the military, as documented above. ${ }^{227}$

Zines (n 118) 289-90.

This is consistent with the view of Mason J in Australian Assistance Plan Case (1975) 134 CLR 338, 398 (Mason J).

226 This sentiment is clearest in the judgment of French CJ in Williams [No 1] (2012) 248 CLR 156, 187:

The subject matters of legislative power are specified for that purpose, not to give content to the executive power. Executive action ... is qualitatively different from legislative action ... To say positively and without qualification that the executive power in its various aspects extends ... to the 'subject matters' of the legislative powers of the Commonwealth is to make a statement the content of which is not easy to divine.

See also at 232 (Gummow and Bell JJ); Appleby and McDonald conclude: '[i]t had been generally accepted since Federation, and reflected in the Commonwealth's policies and conduct, that the breadth of the Commonwealth Executive's capacities followed "the contours" of the Commonwealth legislative powers. This assumption has been displaced by Williams': Appleby and McDonald (n 169) 256 .

227 Moore would permit the use of the military in internal security operations where this meets the test of 'necessity': Moore, Crown and Sword (n 33) 203. 


\section{Section 61 Permits the Commonwealth to Do Things Peculiarly Adapted to the Government of a Nation and Which Cannot Otherwise be Carried on for the Benefit of the Nation}

Despite this criterion also being criticised on the basis of its elusive meaning and subjectivity, ${ }^{228}$ and for its potential to be abused, ${ }^{229}$ again it has enjoyed strong judicial support.

Given the potential for the power to be abused, with the federal government claiming there is an 'emergency' or 'crisis' justifying resort to the power, and the point that these are not, in themselves, criteria of constitutional power for the Commonwealth, ${ }^{230}$ meaningful limits are possible. The High Court might interpret the power as one that is purposive in nature. ${ }^{231}$ This would require the federal government to demonstrate how its executive measures were, in fact related to a purpose of defending the nation in circumstances where, practically, it could not otherwise be carried out. Further, it would need to show the proportionality of its measures to this purpose. If a measure was not proportionate to this purpose, going well beyond what was necessary to defend the nation, or going well beyond what could not practically otherwise be carried out, the Court could find the action was not supported by section 61 . The High Court has already applied proportionality concepts to section $61 .^{232}$

In the context of the implied constitutional freedom of political communication, the High Court has considered three aspects regarding proportionality - whether the particular measure is suitable, necessary and adequate in its balance. ${ }^{233}$ It is possible the High Court might adopt a similar approach to questions of proportionality in the context of a head of power, though note the different context - the implied freedom being a limitation on government power, the head of power being an enabler of government power. ${ }^{234}$

The High Court has already indicated exploration of scientific knowledge and technology would be within the nationhood power. ${ }^{235}$ In the Australian Assistance Plan Case, Mason J found the Commonwealth's power in this regard would extend to matters of public health, including research and advocacy. ${ }^{236}$ Again, the mere fact it is more convenient to regulate a particular thing at national level does not meet the test for use of section 61 .

It is relevant to consider the practical ability of state governments to perform the tasks deemed necessary. The High Court has been sensitive to this aspect in determining this requirement. For instance, in Pape it was clear that the states lacked the financial capacity to provide the kind of economic stimulus the federal

228 Gerangelos (n 118) 104; Hanna (n 216) 340-2.

229 Gerangelos (n 118) 118.

230 Pape (2009) 238 CLR 1, 121-2 (Hayne and Kiefel JJ dissenting).

231 Lindell observed that the nationhood power was purposive in nature, such as would suggest that a proportionality test be applied: Lindell (n 105) 45.

232 Davis (1988) 166 CLR 79, 99-100 (Mason CJ, Deane and Gaudron JJ).

233 McCloy v New South Wales (2015) 257 CLR 178, 217 (French CJ, Kiefel, Bell and Keane JJ) ('McCloy').

234 For an attempt to apply these in the context of executive power see Hanna (n 216) 364-5.

235 Australian Assistance Plan Case (1975) 134 CLR 338, 362 (Barwick CJ), 397 (Mason J); A-G (Victoria) $v$ Commonwealth (1945) 71 CLR 237, 254 (Latham CJ) ('A-G (Victoria)').

236 (1975) 134 CLR 338, 397; as did Latham CJ in $A$-G (Victoria) (1945) 71 CLR 237, 254. 
government sought to provide. ${ }^{237}$ If it was deemed necessary in Pape, it must be deemed necessary for COVID-19, involving crises on both the health and economic fronts, with a much larger financial bailout involved than occurred as a response to the global financial crisis. Relatedly, the Court has stated that the ambit of the Commonwealth executive power is 'clearest' in cases where there is no real competition with state executive or legislative competence. ${ }^{238}$ An example where such would be the case would include a situation involving an agreement between the federal and state government on a particular course of action. Such schemes have been held to be within the Commonwealth's executive power. ${ }^{239}$ We have witnessed impressive co-operation between the federal and state governments on a co-ordinated response to COVID-19, and the bushfire crisis. Again, the federal government is playing an essential role here. As well as providing the financial response, it is co-ordinating critical decision-making on the health and economic fronts. It is working with the states to make these decisions, and then implement them. It is simply not possible that this type of response could occur without the involvement of the federal government. Frankly, it is difficult to describe a situation better befitting the phrase 'cannot otherwise be carried on for the benefit of the nation' than the federal Government's part in responding to COVID-19.

The involvement of its military personnel has been important in this response. The military was responsible for the large-scale evacuation of parts of Victoria over the 2019-2020 bushfire season. It is not clear which other organisation(s) would have had the capability of doing so. The use of the military in relation to response to COVID-19 has been less critical. Military expertise in transportation and logistics has been important. Although the military provided important support to state police, including in relation to enforcing border crossing limits, quarantine restrictions and transfer of individuals from airports to quarantine facilities, the role of Defence here is less clear, and it is less easy to argue involvement of the ADF was critical or necessary, as opposed to merely convenient. For these reasons, in relation to the use of defence personnel in response to the bushfires and COVID19 , it is concluded the federal Government is on stronger constitutional territory using section 51(vi) as a basis, rather than the executive power.

\section{RESTRICTIONS ON MOVEMENT BETWEEN STATES AND TERRITORIES}

Finally, the media is reporting that ADF personnel have been assisting state and territory police in enforcing restrictions that have been introduced by most states and territories in relation to movement across borders. ${ }^{240}$ Some states

240 Felicity James, Katrina Beavan and Henry Zwartz, 'NT Police to Conduct Random Checks on People in Self-Isolation as Part of Territory-Wide Lockdown', ABC News (online, 24 March 2020)

$<$ https://www.abc.net.au/news/2020-03-24/nt-coronavirus-border-restrictions-begin/12081874>: 
effectively closed their borders, with limited exceptions. ${ }^{241}$ At the time of writing this article, border restrictions on interstate movement were substantial and severe. In some cases, interstate movement was generally prohibited, unless a (limited) exemption applied. However, by early 2021, these restrictions had substantially been relaxed.

At the time of writing this article, it was considered that these restrictions raised a constitutional issue, because section 92 of the Constitution relevantly provides that 'intercourse' among the states is to be absolutely free. It also provides trade and commerce is to be absolutely free. While most members of the High Court had not interpreted the word 'absolutely' literally, and did in fact permit some restrictions on the movement of trade, commerce and people across borders, it was considered there was a reasonable prospect of a successful challenge. There had been successful constitutional challenges on the basis of section 92 to restrictions on individuals travelling between states. ${ }^{242}$

However, all five members of the High Court who heard a section 92 challenge to Western Australia's severe border restrictions recently dismissed the challenge. ${ }^{243}$ The Court accepted the argument of the Western Australian government that there was no reasonable alternative to achieving its legitimate objective of protecting public health, other than to impose the harsh border restrictions. ${ }^{244}$ I must respectfully disagree with this critical finding. It is submitted that several alternatives, all of which were less invasive of the constitutional freedom, were available towards achievement of the objective of protecting public health. These alternatives included a partial border closure, for instance closing the border to those who had recently been in Victoria, given that state's high death toll from COVID-19, or a requirement that all entrants could show they had tested negatively to the virus, or a requirement that all arrivals quarantine for a certain period. This decision could herald a significant change in how the High Court applies section 92 to factual scenarios.

It is beyond the scope of the current article to discuss those changes in detail, but they essentially involve a test that now focusses on whether the impugned law discriminates against interstate trade, commerce or intercourse, together with a proportionality test. ${ }^{245}$ This proportionality test would be utilised in a similar way to how it had been applied in the context of the implied freedom of political communication, considering whether the law was suitable, necessary and adequate in its balance. ${ }^{246} \mathrm{~A}$ law would be suitable if it was rationally connected to the disclosed purpose. It would be necessary if there was no obvious and compelling

'Australian Defence Force personnel will join police in monitoring traffic at Northern Territory borders from 4:00pm today in an effort to stop the spread of COVID-19'.

241 See, eg, Quarantine (Closing the Border) Directions made under the Emergency Management Act 2005 (WA) ss 61,70,72A, and the Border Restrictions Direction (No 5) issued pursuant to the Public Health Act 2005 (Qld) s 362B.

$242 \quad R$ v Smithers; Ex Parte Benson (1912) 16 CLR 99; Gratwick v Johnson (1945) 70 CLR 1.

243 Palmer $v$ Western Australia [2021] HCA 5 ('Palmer').

244 Ibid [80] (Kiefel CJ and Keane J).

245 Ibid [62] (Kiefel CJ and Keane J) and [265] (Edelman J); cf [151] (Gageler J) and [190]-[191] (Gordon J). 
alternative to achieving the legitimate objective in a manner less invasive of the freedom. Whether it was adequate in its balance would be determined having regard to the importance of the objective sought to be obtained, balanced with the importance of the right being infringed, and the extent to which the law infringed it. ${ }^{247}$ The High Court also moved in Palmer $v$ Western Australia ('Palmer') to adopt similar approaches in respect of trade and commerce as those applied to intercourse. ${ }^{248}$ This is a substantial departure from the previous test applied to section 92 cases ${ }^{249}$ contained in the Cole $v$ Whitfield decision.

Some care is required before accepting that a change in approach to the interpretation of section 92 has definitely occurred, given that the decision was unfortunately that of only five judges, not seven. Further, two justices of the three in the majority are due to retire within the next three years. We do not know the approach of the newly appointed members of the High Court, Steward and Gleeson JJ, towards the question of proportionality in constitutional interpretation. Thus, it is not known whether the change in interpretation to section 92 heralded in Palmer, involving the discarding of the 'protectionist purpose' requirement and a focus on proportionality in its stead, will be a permanent one.

These changes are welcome, ${ }^{250}$ even if the result obtained from applying them to the Western Australian legislation was not, at least in my personal view. It is accepted that not all will support the change. A satisfactory interpretation of section 92 had eluded the High Court for many years, and it is understandable that some would seek to uphold the approach found in the unanimous decision in Cole $v$ Whitfield that had apparently finally settled an interpretation to the section.

Arguably, one of the regrettable features of the generally very successful response of Australian governments collectively to the COVID-19 crisis has been a step backwards to a loose collection of colonies, with their inevitable parochialism and provincialism, and an undermining of our united national identity. This is not a development to be welcomed, and it is hoped that this reversion is a temporary lapse, rather than reflecting a permanent re-ordering of Australian constitutional affairs. The founding fathers' vision was to create a unified nation where business and personal movement around Australia was to be seamless, realising the economic and social benefits of federation. Section 92 was one of the few express rights enshrined in the Constitution. The vision of the founding fathers should not be undercut by populist political measures that cynically play on individuals' legitimate fears to assert greater state power over the individual. Respectfully, the High Court should uphold the Constitution, and the vision of the founding fathers.

247 Ibid 195 (French CJ Kiefel Bell and Keane JJ).

248 Palmer [2021] HCA 5, [62] (Kiefel CJ and Keane J); [114] (Gageler J); [181] (Gordon J) and [241] (Edelman J).

249 Cole $v$ Whitfield (1988) 165 CLR 360, where all members of the Court adopted a test focussed on discrimination and establishment of a protectionist purpose.

250 Anthony Gray 'COVID-19, Border Restrictions and Section 92 of the Australian Constitution' in Augusto Zimmermann and Joshua Forrester (eds) Fundamental Rights in the Age of COVID-19 (Connor Court Publishing, 2020) 99; Anthony Gray 'Section 92 of the Constitution: The Next Phase' (2016) 44(1) Australian Business Law Review 35, 44-9. 


\section{CONCLUSION}

This article has considered use of the military in the context of two crises with which Australia has recently grappled and continues to grapple. This raises significant issues regarding the extent of Commonwealth constitutional power to deal with 'emergencies'. It has concluded that the relevant provisions of the Defence Act 1903 (Cth) are likely supported by the defence power, together with the incidental power. Greater difficulty attends use of the executive power and/or the inherent nationhood power. It was concluded that the Commonwealth has constitutional powers to deal with the bushfire emergency and COVID-19 crisis by virtue of its executive powers, the Constitution being flexible enough to permit the federal government power regarding 'emergencies'. However, the federal government should be cautious with its use of military here, due to debate as to whether it is 'necessary' in relation to executive power, as opposed to mere convenience. In that regard, the Commonwealth would be on stronger ground using the defence power rather than executive power. 